\title{
Sağlık Çalışanlarının Öz Liderlik Düzeylerinin Sosyo-Demografik Değişkenler Açısından İncelenmesi
}

\section{Examination of the Self-Leadership Level of Health Workers in Terms of Socio-Demographic Variables}

\author{
Cuma Çakmak ${ }^{\mathrm{a}, *}$, Özgür Uğurluoğlu ${ }^{\mathrm{b}}$

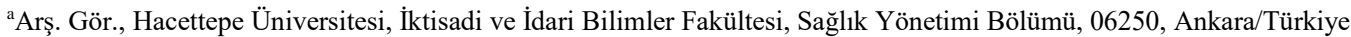 \\ ORCID: 0000-0002-4409-9669 \\ bDoç. Dr., Hacettepe Üniversitesi, İktisadi ve İdari Bilimler Fakültesi, Sağlık Yönetimi Bölümü, 06250, Ankara/Türkiye \\ ORCID: 0000-0002-9453-9925
}

\section{MAKALE BİLGİSI}

Makale Geçmişi:

Başvuru tarihi: 04 Eylü 2018

Düzeltme tarihi: 12 Aralık 2018

Kabul tarihi: 02 Ocak 2018

\section{Anahtar Kelimeler:}

Hastane

Sağlık Çalışanları

Öz liderlik
ÖZ

Bu çalışmanın amacı, sağlık çalışanlarının öz liderlik düzeylerinin sosyo-demografik özelliklerine göre farklılaşıp farklılaşmadığı belirlemektir. Araştırma, Ankara'daki bir eğitim ve araştırma hastanesinde görev yapan sağlık çalışanlarına yönelik gerçekleştirilmiştir. Anketler yoluyla, araştırma kapsamında 357 sağlık çalışanına ulaşılmış ve bu kişilerden elde edilen veriler değerlendirilmiştir. Sağlık çalışanlarının öz liderlik alt boyutlarıyla ilgili değerlendirmelerinin sosyo-demografik özelliklere göre farklılaşıp farklılaşmadığını ortaya koymak amacıyla iki ortalama arasındaki farkın önemlilik testi (standart $t$ testi) ve tek yönlü varyans analizi (F testi-ANOVA) kullanılmıştır. Gruplar arasında anlamlı farklılıklar bulunması durumunda anlamlılığın hangi gruptan kaynaklandığını bulmak amacıyla Post-hoc testlerinden biri olan Tukey HSD testinden faydalanılmıştır. Analizler sonucunda, öz liderliğin alt boyutlarına ilişkin ortalamalar, çalışanların, cinsiyet, yaş, medeni durum, hastanedeki görev, gelir durumu, sektördeki toplam çalışma süresi ve çalışanların liderlik eğitimi alıp almama durumlarına göre istatistiksel olarak anlamlı bir şekilde farklılaşmaktadır. Sonuç olarak, sağlık çalışanlarının sosyo-demografik özelliklerine göre öz liderlik düzeylerinin farklılaştı̆̆ tespit edilmiştir.

\section{A B S T R ACT}

The aim of this study is to determine whether the self-leadership levels of health workers differ according to socio-demographic characteristics. The research was carried out with health workers working in a training and research hospital in Ankara and 357 health workers were reached within the scope of the research. The significance test (standard $t$ test) and one-way variance analysis ( $F$ test-ANOVA) were used for the difference between the two means in the study. In the case of significant differences between the groups, the Tukey HSD test, one of the post hoc tests, was used to find out which group resulted in meaningfulness. As a result of the analyzes, averages of the subdimensions of the self-leadership differ statistically according to the employees 'gender, age, marital status, the duties in the hospital, the income situation, the total working time in the sector and the employees' leadership education. As a result, it has been determined that self-leadership levels differ according to socio-demographic characteristics of health workers.

\section{Giriş}

Geleneksel liderlik yaklaşımlarının günümüz koşullarına uygun olmadığı düşünülmekte ve liderin, emir veren olarak görüldüğ̈̈, takipçilerini ardından sürüklediği klasik liderlik imgesinin günümüz modern toplumlarında, modern örgütlenmelerinde ve işletmelerinde kendisine yer bulamadığı iddia edilmektedir.

Geleneksel olarak liderlik yaklaşımlarının çoğu, formal liderlik pozisyonlarına kimlerin getirileceği ile ilgilidir. Geleneksel liderlik yaklaşımlarının aksine, Pearce ve Manz

\footnotetext{
* Sorumlu yazar/Corresponding author.

e-posta: cumacakmak@hacettepe.edu.tr
} 
(2005; 130) takipçilerin, liderlik yaklaşımlarının geliştirilmesine dâhil edilmesi gerektiğini ifade etmektedir. Liderler, ticari kazanç elde etmenin ötesinde, işgücünün değişen beklentilerini göz önüne almalıdır. Bugünün çalışanları, işlerini, sadece maaştan ibaret olarak görmekten öte kendilerini mutlu eden, yeteneklerini geliştirdikleri bir araç olarak görmektedirler. Nihayetinde, insanlar işleri ile ilgili kararlarda giderek artan derecede kontrol sahibi olmayı beklemektedir. Bu beklenti, liderin, geleneksel liderlikten farklı şekillerde takipçileri ile etkileşime girmesini gerektirmektedir (Yun, Cox, \& Sims, 2006: 375).

Günümüz işletmeleri, hayatta kalabilmek ve yaşamlarını sürdürebilmek için her geçen gün gelişen teknolojiye ve küresel çevreye uyum sağlamak zorundadır. Geçen yüzyılın liderlik modelleri, yukarıdan aşağıya bürokratik paradigmaların ürünü olmuştur. Bu liderlik modellerinin, fiziksel üretim odaklı ekonomiler için oldukça etkili olduğu ancak bilgi odaklı ekonomiler için ise uygun olmadığı görülmektedir (Uhl-Bien, Marion, \& McKelvey, 2007: 298). Günümüzde, güçlendirilmiş işgücüne doğru bir eksen kayması gerçekleşmektedir. Bu sebeple ortaya birçok soru çıkmaktadır. Geleneksel liderlik model ve yaklaşımlarının günümüz örgütleri için hala uygun olup olmadığı, bu model ve yaklaşımların geliştirilmesi ve yeniden yapılandırılmasına ihtiyaç duyulup duyulmadığı soruları sorulmaktadır. Akademik çalışmalar, liderlik revizyonuna olan gereksinimin artma eğiliminde olduğunu göstermektedir. Örgütlerin büyümesi, liderin üzerine düşen görevlerin artması, örgüt performansı ve kârın artırılmak istenmesi gibi nedenler, iş görenlerin liderlik sürecine dâhil edilmesi gerektiğini gündeme getirmektedir. Dolayısıyla son yıllarda, liderlik literatüründe tartışılan öz liderlik (selfleadership) anlayışının güçlendiği görülmektedir. Tüm dünyada öz liderliğe ilişkin ilginin, araştırmacılar ve uygulayıcılar tarafindan kabul gördüğ̈̈ görülmektedir (Tabak, Sığrı, \& Türköz, 2013: 214-218; Bligh, Pearce, \& Kohles, 2006: 297). Öz liderliğe ilişkin ilginin nedenlerini ise DiLiello ve Houghton (2006: 326); öz liderliğin, 21. yüzyılın zorlukları ile yüzleşmek zorunda olan örgütlerin, örgütsel kapasitelerini artırmaları için umut verici olması, yaratıcı problem çözmeyi teşvik eden sosyal ve psikolojik iklim oluşturmak için önemli örgütsel bir araç olması, öz liderliği teşvik eden bir organizasyonun üyeleri arasında daha yüksek seviyede yaratıcı süreçler yaşanabilmesi, öz liderliğin pratikte uygulanması ile potansiyelin ortaya çıkarılması, yenilikçilik ve yaratıcılığın yüksek düzeyde yaşanılması ile açıklamaktadır.

İşletmeler arasında yoğun rekabetin artmasıyla işletmelerin yaşamlarını devam ettirebilmeleri, başarılı olmaları ve değişime ayak uydurabilmelerinin yolu güçlendirilmiş, öz liderlik becerileri sergileyebilen çalışanlardan geçmektedir. $\mathrm{Bu}$ çalışanlara olan ihtiyaç giderek artmaktadır. Bu sebepten ötürü, beşeri sermayeye yatırım yapılması gerekliliği ortadadır (Doğan \& Şahin, 2008: 145). Günümüz örgütlerinin karşılaştıkları bir başka zorluk da çalışanlarının sahip olduğu yeteneklerin nasıl ortaya çıkarılacağının bilinmemesidir. $\mathrm{Bu}$ tür örgütlenmelerin çoğu, liderin başkalarına, kendi kendilerinin liderleri (öz lider) olmalarını öğretmekten öte bağlılık ve uyumu teşvik eden yarı askeri bir model ile çalışmaktadır (Manz \& Sims, 1991: 19). Çalışanların eğitim düzeylerinin yükselmesi, mesleklerine olan bağlılıkların artması, işlerinde maddi beklentilerin ötesinde başka beklentilerin de ortaya çıkmasından (örneğin, çalıșanın karar alma sürecine dâhil olmayı beklemesi) ötürü klasik yönetim biçimlerinin yetersiz kaldığı görülmekte ve bu yeni duruma uygun liderlik biçiminin öz liderlik olabileceği görülmektedir (Bakan, 2008: 18). Öz liderliğin odak noktası, kişilerin içsel enerjilerinin ortaya çıkarılmasıdır. Bu yeni perspektif liderin gücünün yeni bir ölçüsüdür. Burada önemli olan liderin kendisini güçsüz duruma getirmesi değil aksine liderin kişinin, örgüte katkılarını maksimize edecek yeteneklerinin geliştirilmesi için liderlik yapmasıdır (Manz \& Sims, 1991: 18-19).

Uluslararası literatür incelendiğinde öz liderliğe önem verildiği görülmektedir (Alves et al., 2006: 341; Bligh et al., 2006: 300; Carmelie, Meitar, \& Weisberg, 2006: 76; Houghton \& Neck, 2002: 673; Neck \& Houghton, 2006: 271; Bryant \& Kazan, 2013:111; Houghton, Dawley, \& DiLiello, 2012: 217). Ulusal literatürde öz liderlik çalışmalarının yetersizliği konunun öneminin tam olarak anlaşılmamasına neden olmaktadır. Özellikle sağlık sektöründe öz liderlikle ilgili yapılan çalışmaların ise (Uğurluoğlu, 2010; Uğurluoğlu, Saygılı, Özer, \& Şantaş, 2015; Kayral, 2015) sınırlı olması, sağlık hizmetlerinde öz liderliğin ve öz liderlik ile ilişskilendirilebilecek diğer kavramların (iş doyumu, iş stresi, performans, vb.) araştırılmasını önemli kılmaktadır. Sağlık çalışanlarının öz liderlik düzeylerini belirlemenin ve öz liderlik düzeylerinin sosyo-demografik özelliklere göre farklılaşıp farklılaşmadıklarını ortaya koymanın; sağlık kurumları yöneticilerine çalışanları arasında söz konusu davranışları teşvik etmek konusunda fayda sağlayacağı düşünülmektedir. Öz liderlik ile ilgili çalışmaların kısıtlı olması nedeniyle öz liderlik pratiklerinin çalışma alanlarında uygulanması ile elde edilecek kazanımların net olarak ortaya konmamış olması bir eksiklik olarak görülmektedir.

$\mathrm{Bu}$ düşünceler temel alınarak yola çıkılan çalışmada sağlık çalışanlarının öz liderlik alt boyutları ile ilgili değerlendirmelerinin sosyo-demografik özellikler açısından farklılık gösterip göstermediğini ortaya koymak amaçlanmıştır.

\section{2. Öz Liderlik Kavramı ve Stratejileri}

Öz liderliği ilk olarak Manz (1986) "kişinin bireysel ve örgütsel başarıyı elde etmesi için kendisini motive etmesi ve yönlendirme süreci” olarak tanımlamıştır. Öz liderlik, bireyin kendisini etkilemede kullanılabileceği düşünce ve davranışlar üzerinde yoğunlaşan, kapsamlı stratejiler bütünüdür. Manz (1986) tarafından kavramsallaştırılan öz liderlik, davranışları yönlendirilecek bir dizi bireysel stratejiye ulaşmak için öz düzenleme, öz kontrol, öz yönetim ve biliş kuramları üzerine kurulmuştur. Ayrıca bu stratejilere ulaşmak için doğal ödüller ve yapıcı düşünce modelleri kullanılır (Manz 1986:589-593). Başka bir deyişle, öz liderlik, kişinin performansını kasıtlı olarak etkileme sürecinin yönetilmesi adına zengin bir psikoloji perspektifi sağlar (Neubert \& Ju-Chien, 2006: 360). Dahası, öz liderlik, karar verme becerilerini, mesleki verimliliği ve kişisel etkinliği artıran, bireyin kendi kendini algılama ve benlik saygısı üzerinde pozitif yönde etki yapan bir öz-yeterlik geliştirme süreci olarak da tanımlanabilir (Kazan, 1999: 7).

Öz liderlik stratejileri, çalışanların öz liderlik becerilerinin geliştirilmesi, çağdaş organizasyonların dinamik ve karmaşık iş sistemlerinden kaynaklı zorlukların yönetilmesinde önemli bir potansiyel sunar. Daha da önemlisi liderlerin üzerindeki taleplerin azaltılmasının 
yolunu açar. Öz liderlik stratejilerinin uygulanması ile uzun vadede çalışanların ihtiyaç duyduğu şekilde kendi yönlerini çizmelerine ve kendilerini yönetecek kapasiteye ulaşmalarına imkân tanınacaktır (Lovelace, Manz, \& Alves, 2007: 380).

Öz liderlik, resmi ve hiyerarşik otoriteyle belirlenmiş liderlerin etkisine ve kontrolüne odaklanan geleneksel liderlik ve örgütsel perspektiflere bir alternatif oluşturmaktadır. Bu alternatif liderlik bakışı, ekip halinde çalışan liderlerin geliştirilmesini sağlamakta ve geleneksel otorite figürü olarak ortada duran kahraman lidere daha az bağımlılık yaratmaktadır (Pearce \& Manz, 2005: 133). Öz Liderlik Kuramı, liderlik kuramlarını köklü bir değişime zorlamaktadır. Bu kurama göre her insanın kendi kendine liderlik edebileceği varsayılmaktadır. Öz liderlik sadece yöneticiler ile ilgili değil; aksine öz liderlik tüm çalışanlar için geçerlidir. Öz liderliğe göre, herkes liderlik enerjisini kendi liderlik biçiminden almaktadır. Buna göre liderliğin yeni koşulu bireyin kendi geleceğini doğru bir şekilde belirleme, kabiliyetlerini tanıma ve bunları en üst seviyede geliştirmesidir (Göksoy, Emen, \& Yenipınar, 2014: 104)

Öz liderlik stratejilerinin temelde üç kategoride incelendiği görülmektedir. Bunlar; 1) davranış odaklı stratejiler (behavior-focused strategies), 2) doğal ödül stratejileri (natural reward strategies), 3) yapıcı düşünce modeli stratejileridir (constructive thought pattern strategies). (Prussia, Anderson, \& Manz, 1998: 524; Houghton \& Neck, 2002: 673; Neck \& Houghton, 2006: 271).

Davranış odaklı stratejiler, etkili davranış ve eylemlerin gerçekleştirilmesine odaklanır (Manz, 1992: 23). Davranış odaklı stratejiler, olumlu duygusal tepkilerle sonuçlanması muhtemel belirli eylemleri veya davranışları seçmeyi içerir (Manz, Houghton, Neck, Fugate, \& Pearce, 2016: 377) Davranış odaklı öz liderlik stratejileri, başarısız sonuçlara götüren olumsuz, istenmeyen davranışların bastırılmasını sağlarken başarılı sonuçlara yol açan olumlu, istenen davranışların da teşvik edilmesini sağlar (D'Intino, Goldsby, Houghton, \& Neck, 2007: 106). Bireyin öz farkındalığının artırılması temel amaç olmakla beraber, ayrıca hoş olmayan davranışların kontrolünü de içermektedir (Neck \& Houghton, 2006: 271). Davranış odaklı stratejiler; bireylerin kendi çalışmalarını daha etkin bir şekilde organize etmelerine ve yönlendirmelerine yardımcı olmak için tasarlanmış stratejilerdir. Bu stratejiler; kendini gözlemleme, kendine hedef belirleme, ipucu yönetimi (hatırlatıcı belirleme), kendini ödüllendirme, yapıcı kendini cezalandırma, öz eleştiri ve prova stratejilerinden oluşur (Manz \& Sims, 1991: 23; Neck \& Houghton, 2006: 271).

Davranış odaklı stratejiler iki adımdan oluşmaktadır. İlk adımda, istenmeyen davranış (statüko davranış) olup olmadığı değerlendirilir. İkinci aşamada, kendi kendine hedef belirleme stratejisi ile davranış değişikliğine (istenilen durum) gidilir. Sonrasında, kendini gözlemleme yoluyla, mevcut ve istenilen durum arasındaki tutarsızlık sürekli olarak izlenir. Kendini ödüllendirme ve cezalandırma stratejisi, hedeflenen, sistematik davranış değişikliğinin gerçekleşmesi için kullanılır. İpuçları (örneğin, yapışkan kâğıtlar, notlar vb.) istenilen hedeflere ulaşmada kolaylaştırıcı bir yardım sağlar (Furtner, Rauthmann, \& Sachse, 2015: 107). Listeler, notlar, ekran koruyucular1 ve motivasyon posterleri, dikkat ve çabanın hedefe ulaşmasında yardımcı olabilecek dışsal ipuçlarına verilebilecek birkaç örnek arasında sayılabilir (Neck \& Houghton, 2006: 272).

Doğal ödül stratejileri, görevin eğlenceli özelliklerine odaklanarak ve bu yanları geliştirerek bireyin yetkinlik ve kendi kaderini tayin etme duygularını artırmayı amaçlamaktadır (Alves et al., 2006: 341). Doğal ödül stratejileri, işin keyif veren ve hoş yönlerini aramakla ilgilidir. Birey, görev performansıyla ilişkili algılarını veya davranışlarını değiştirerek doğal ödül stratejilerini kolaylaştırabilir ve böylece bireyin algılanan yeterlilik, kendini kontrol veya görev sorumluluğu artabilir (Prussia et al., 1988: 524). İnsanların yaptıkları işten hoşlanmaları durumunda daha iyi performans göstereceği düşünülmektedir. Öz liderliğinin önemli bir kısmı, işin kendisinden kaynaklanan potansiyel doğal ödüllerden yararlanmayı gerektirmektedir. Doğal ödüller, çalışma ve kişisel yaşamın bir parçası olarak nasıl geliştirebilir (Manz \& Sims, 2001: 94-95) sorusuna aranan cevap doğal ödül stratejileri kapsamında değerlendirilmektedir. Dolayısıyla, önemli olan doğal ödüllerin nasıl elde edeceğidir.

Doğal ödül stratejileri, bir göreve ilişkin olumlu deneyime ve elde ettiği sürece odaklanır (Carmelie et al., 2006: 77). Deci ve Ryan'a göre (1985: 1026) yapılan birçok çalışma ödüllerin içsel motivasyonu artırdığını ortaya koymuştur. Doğal ödül odaklı stratejiler, doğal olarak ortaya çıkan içsel, duygusal deneyimlerle olan bağlantılara odaklanır (Manz et al., 2016: 377). Doğal ödül stratejileri, öz liderlik stratejilerinin merkezinde bulunur. İnsanların görevleri ile ilişkili içsel motivasyon sağlamada doğrudan etkiye sahiptir (Furtner et al., 2015: 107). Doğal ödül stratejileri, çalışanın günlük yaşam pratiğinde ve çalışma yaşamında, çalışana yeterli olduğu hissini vermekte, çalışma ve başarma güdüsünü artırmada kullanılmaktadır. Ayrıca işlerin neşeli yönlerine odaklanarak bireyin performansında bir artış yaşanacağını belirtmektedir (Doğan \& Şahin, 2008: 144, Uğurluoğlu vd., 2015: 6). Özetlemek gerekirse, doğal ödül stratejileri, yetkinlik ve kendi kaderini tayin etme hissi yaratmaya yardımcı olmak üzere tasarlanmıştır. Dolayısıyla, performansı artıran görevle ilgili davranışların güçlenmesini sağlamaktadır (Neck \& Houghton, 2006: 272; D'Intino et al., 2007: 107).

Doğal ödül stratejileri; 1) doğal ödüller üzerine göreve odaklanma, 2) doğal ödüller üzerine düşünceyi odaklama olmak üzere iki kategoriye ayrılır. Doğal ödül stratejilerin, birincisi kişinin işine, kendisinden bazı hoş, zevk verici özellikler katmayı gerektirir. Böylelikle, iş kişiye doğal bir ödül olarak görülmektedir. İkinci strateji ise, işin hoş olmayan taraflarından uzaklaşmayı ve işin ilgi çekici taraflarına odaklanmayı gerektirir. Doğal ödül stratejileri kapsamında olan bu iki strateji de, bireyin çalışma gayretini, yeterliliğini olumlu etkilemektedir. Dolayısıyla, motivasyonu yükseltmektedir (Doğan \& Şahin, 2008: 143144). Kişinin soft bir müzik çalması, duvara resimler asması veya kişisel dokunuşlar ile daha keyifli bir çalışma ortamı yaratmaya çalışması bu strateji kapsamda değerlendirilmektedir. Alternatif olarak, bir kişi zihinsel olarak, dışarıda çalışma veya müşterilerle konuşmak gibi işin keyif veren yönlerine bakabilir. $\mathrm{Bu}$ gibi doğal ödül stratejileri kullanılarak, işin hoş yönlerine odaklanılır ve böylelikle performans seviyeleri artırabilir (Houghton, Neck, \& Manz, 2003: 16). 
Öz liderlik, esas olarak bireylerin düşünce kalıplarını yapıcı bir şekilde yönetme süreciyle ilgilidir ve bu da eylemi etkilemektedir. Davranışların içinde alışkanlıklar geliştirildiği gibi düşüncelerin içinde de alışkanlar ve kalıplar geliştirilmektedir. Örneğin, zihin, fırsatlar veya engellere yönelik alışkanlıklar geliştirebilmektedir. Zor olan, düşünce kalıplarının, iş yaşamında ve kişisel yaşantıda verimliliği artıracak bir şekilde yönetilmesidir (Manz \& Sims, 2001: 108). Yapıcı düşünce modeli, başarılı öz liderlik için önemli bir unsurdur (Manz \& Sims, 1991: 26). Yapıcı düşünce modeli stratejileri, uzun vadede öz liderlik becerilerinin sergilenmesinde en umut verici yaklaşımlar olarak değerlendirilmektedir (Doğan \& Şahin, 2008: 144). Yapıcı düşünce süreçleri, pozitif düşünme aracılığıyla bireyde olumlu düşünce yaratmay1, işlevsiz inanç ve varsayımların, negatif içsel konuşmanın azaltılması ve bireyin kendisine yönelik pozitif imajın arttırılmasını amaçlamaktadır (Alves et al., 2006: 341).

Yapıcı düşünce stratejileri, düşünce kalıplarının daha pozitif olanlar ile değiştirilmesidir. Zihinsel stratejiler aracılığıyla, olumsuz düşünce iyimser kendi kendine konuşma ile değiştirilir. Yapıcı düşünceye ulaşmak için dört zihinsel strateji veya adıma ihtiyaç vardır (Bryant \& Kazan, 2013: 111-112);

\section{1. İnanç sistemini iyileştirmek.}

2. İstenilen performansı kolaylaştırmak için hayal gücünü kullanmak.

3. Avantaj elde etmek için kendi kendine konuşmayı kullanmak

4. Yeni ve gelişmiş senaryoların öğrenilmesi ve kullanılması.

Yapıcı düşünce modeli stratejileri, düşünce kalıplarını arzu edilen yollarla kurma ve değiştirmeye odaklanır. Düşünme kalıplarını değiştirmek için dört özel strateji kullanılabilir. Bunlar; kendini analiz etme ve inanç sistemlerinin geliştirilmesi, olumlu performans sergilemeye yönelik zihinsel imge, performansı kolaylaştırmak için olumlu kendi kendine konuşma ve etkisiz olan senaryolar yerine pozitif olanların kullanılması (Prussia et al., 1988: 524). Yapıcı düşünce stratejilerini kullananların, zorluklar karşısında yapıcı yaklaşımlar içerisinde bulunması, alışkanlık haline getirdikleri işlevsel ve firsat odaklı bir düşünme modeli geliştirmelerinin muhtemel olduğu görülmektedir (Houghton \& Jinkerson, 2007: 46).

\section{Sağlık Hizmetlerinde Öz Liderlik}

Geçmişin sağlık hizmeti tüketicileri, sağlık hizmetlerinde kullanılan yöntemler veya sağlık hizmetinin maliyetleri ile ilgilenmemekte iken mevcut sağlık hizmeti tüketicileri sağlıkla ilgili her türlü bilgiye sahip olmakla beraber kaliteli sağlık hizmeti istemekte ve sağlık hizmetinin uygun bir fiyatla sunulmasını da talep etmektedir. Modern sağlık hizmeti tüketicileri, kendilerinin hasta olarak değil, kaliteli sağlık hizmetini uygun fiyat ile talep eden, bilgiye sahip ve sağlıkla ilgili karar alma sürecine dâhil edilmeyi isteyen rasyonel sağlık hizmeti tüketicileri olarak görülmeyi istemektedir (Griffin, 1998). Sağlık kuruluşlarının günümüz koşullarına ayak uydurabilmesi ve bu koşullara geçişte gerekli değişikliklerin uygulanabilmesi güçlü liderler gerektirmektedir. Çalışanların yüksek performansla çalışabilmesi ve çalıştıkları kurumlarının da müşteri odaklı olabilmesi için çalıșanlarını motive edebilen ve çalıșanlarına rehberlik edebilecek güçlü liderlere ihtiyaç vardır (Watson, 2004). Güçlü liderlik, profesyonel özerkliği ve klinik yönetimi güçlendirmekle beraber çalışanların, hastaların ve toplumun ihtiyaçlarına daha fazla odaklanmasına hiyerarşik ve idari sistemlerin ihtiyaçlarına ise daha az cevap vermeye yönelmelerini sağlamaktadır (Solà et al., 2016: 2). Sağlık çalışanlarının; hastaların ve toplumun ihtiyaçlarına odaklanabilmesi ise sağlık kuruluşlarında hiyerarşik liderlik paradigmalarının yerine alternatif liderlik yaklaşımlarının uygulanmasıyla mümkündür. $\mathrm{Bu}$ bağlamda, sağlık çalışanları için öz liderlik becerilerinin geliştirilmesi önemlidir. Sağlık çalışanları ve organizasyonları, liderlik becerilerini sürekli değerlendirip geliştirerek, bireysel büyümeyi teşvik eden ve gelecekteki başarıları için liderleri eğiten bir çalışma ortamı oluşturabilmelidirler.

Sağlık çalışanlarının öz liderlik becerilerinin geliştirilmesi başka bazı faydalar da sağlamaktadır. Öz liderlik, çalışanların işleri ile ilgili algılarında değişiklik yaratmaktadır (Neck \& Milliman 1994: 14). Yapılan çalışmalar, örgütte öz liderlik becerilerinin teşvik edilmesi ile çalışanların psikolojik fonksiyonlarında (etkili başa çıkma, dayanıklılık, optimist olma ve kişiler arası dürüstlük, iş doyumu, etkili iş ilişkileri) ve sağlık statülerinde (iyilik halinin yükselmesi, stresin düşmesi, hastalık semptomlarının azalması) olumlu gelişmelerin yaşandığını ortaya koymuştur (Dolbier, Soderstrom, \& Steinhart, 2001: 460). Prussia et al. (1998: 523)'ne göre, öz liderlik performansı artıcı etki yaratmaktadır. Sağlık hizmetleri yüksek performans ve özveri istemektedir. Sağlık çalışanlarının performans düzeylerinin artırılmasında öz liderlik önem taşımaktadır. Carmelie et al. (2006: 75)' a göre, öz liderlik yenilikçi davranışların sergilenmesini sağlar. Sağlık hizmetlerinde spefisik hastalıklara çözüm aramak, insan hayatını kolaylaştıracak buluş üretmek, insan sağlığını ileriye taşımak adına önemli ve anlamlıdır. Sağlık çalışanlarının yenilikçi davranışlar geliştirmesinde öz liderliğin önemli bir rolünün olabileceği ifade edilebilir. Öz liderlik aynı zamanda stresli iş ortamının yönetilmesinde çalışanlara yardımcı olmaktadır (Lovelace et al., 2007: 374). Öz liderliğin stresi azalttığ1 ve bireyde olumlu etkiler yarattığı tespit edilmiştir. Öz liderlik eğitiminin stres yönetimine bireysel düzeyde önleyici bir yaklaşım sunduğunu ortaya koyulmuştur (Unsworth \& Mason, 2012: 235). Sağlık çalışanlarının günün yirmi dört saati ve nöbet usulü çalıştıkları, insan hayatını belirleyen kararların anlık verilmesinin gerekli olduğu bir iş ortamında çalıştıkları düşünüldüğünde stresli bir işe sahip oldukları söylenebilir. Dolayısıyla, öz liderliğin stresli iş ortamlarında çalışan sağlık çalışanlarının iş streslerinin yönetilmesinde sağlık çalışanları ve yöneticilerine yol gösterebileceği söylenebilir. Yonghee ve Youngrye (2013: 462)'nin hemşireler üzerinde gerçekleştirdikleri çalışmanın sonuçlarına göre, hemşirelerin öz liderlik, işe bağlanma ve klinik yeterlikleri arasında anlamlı pozitif ilişkiler ortaya koyulmuştur. Seunghye et al. (2014: 206)'ın hemşireler üzerinde gerçekleştirdikleri çalışma sonuçlarına göre, öz liderlik, güçlendirme ve iş doyumu arasında pozitif yönlü ve anlamlı ilişkiler ortaya koyulmuştur. Nam Young ve Sun Young (2011: 216)'ın hemşirelik eğitimi alan öğrencilere yönelik gerçekleştirdiği çalışma sonuçları, öz liderlik, iş doyumu ve iş stresi arasında anlamlı ve pozitif ilişki olduğu ortaya koyulmuştur. Öz liderlikle ilgili sağlık çalışanlarına yönelik 
gerçekleştirilen çalışmalar öz liderliğin iş doyumunu ve iş stresi ile ilişkisinin olabileceğini ortaya koymaktadır.

Uğurluoğlu $(2010 ; 175)$ tarafindan Ankara'da özel bir hastanenin çalışanlarına yönelik gerçekleştirilen çalışmaya göre, öz liderlik stratejilerinden olan davranış odaklı stratejiler ve doğal ödül stratejilerinin çalışanların iş doyumunu pozitif yönde etkilerken, yapıcı düşünce modeli stratejilerinin iş doyumunu negatif yönde etkilemektedir. Gaziantep’te özel bir hastanenin sağlık çalışanlarına yönelik gerçekleştirilen bir başka çalışmaya göre, sağlık çalışanlarının öz liderlik becerilerinin, iş doyum düzeyleri ve iş performanslarını etkilemektedir. Ayrıca yapıcı düşünce stratejilerinin iş performansı üzerinde, davranış odaklı stratejilerin ise iş doyumu üzerinde daha etkili olduğu ortaya koyulmuştur (Kayral, 2015; 113).

Sınırlı olmasına rağmen ulusal ve uluslararası çalışmaların, öz liderliğin sağlık çalışanlarının iş doyumu ve iş stresi üzerinde etkilerinin olabileceğini ortaya koymaktadır.

\section{Gereç ve Yöntem}

\subsection{Araştırmanın Amacı ve Önemi}

$\mathrm{Bu}$ çalışmanın amacı, (1) sağlık çalışanlarının öz liderlik düzeylerinin saptanmasi/belirlenmesi ve (2) öz liderlik düzeylerinin sosyo-demografik özelliklerine (yaş, cinsiyet, medeni durum, eğitim durumu, hastanedeki görev, gelir, çalışma süresi, liderlik eğitimi alıp almama) göre farklılık gösterip göstermediğini ortaya koymaktadır. Sağlık çalışanlarının öz liderlik düzeylerinin saptanması ve sosyodemografik özelliklerine göre farklılaşıp farklılaşmadığının belirlenmesinin söz konusu değişkenlerin öz liderlik stratejilerini etkileyebileceği ve öz-liderlik kavramının anlaşılması ve kullanılması açısından kritik öneme sahip olduğu düşünülmektedir. Ayrıca Öz liderlik ile ilgili çalışmaların ulusal literatürde az sayıda olduğu söylenebilir. Özellikle sağlık çalışanlarını kapsamına alan çalışmaların ise (Uğurluoğlu, 2010; Kayral, 2015) çok kisıtlı olduğu literatür incelendiğinde görülecektir. Öz liderliğin araştırmacılar tarafindan hem bireysel hem de örgütsel anlamda çağdaş bir reçete olarak sunulduğu günümüzde, öneminin anlaşılması ve pratikte uygulanabilirliğinin artırılması için bu çalışmasının önemli olduğu, sağlık çalışanları özelinde yapılması, sağlık sektörü ve sağlık çalışanlarını kapsamına alan gerek uluslararası gerek ulusal çalışmaların sınırlı olmasından ötürü de bir boşluğu doldurmaya yönelik olduğu söylenebilir.

\subsection{Araştırmanın Hipotezleri}

$\mathbf{H}_{1}$ : Sağlık çalışanlarının cinsiyet değişkenine göre öz liderlik düzeyleri istatistiksel olarak anlamlı farklılıklar göstermektedir.

H2: Sağlık çalışanlarının yaş değişkenine göre öz liderlik düzeyleri istatistiksel olarak anlamlı farklılıklar göstermektedir.

H3: Sağlık çalışanlarının medeni durumlarına göre öz liderlik düzeyleri istatistiksel olarak anlamlı farklılıklar göstermektedir.

H4: Sağlık çalışanlarının eğitim durumlarına göre öz liderlik düzeyleri istatistiksel olarak anlamlı farklılıklar göstermektedir.
H5: Sağlık çalışanlarının hastanedeki görevlerine göre öz liderlik düzeyleri istatistiksel olarak anlamlı farklılıklar göstermektedir.

H6: Sağlık çalışanlarının gelirlerine göre öz liderlik düzeyleri istatistiksel olarak anlamlı farklılıklar göstermektedir.

H7: Sağlık çalışanlarının sektörde çalışma sürelerine göre öz liderlik düzeyleri istatistiksel olarak anlamlı farklılıklar göstermektedir.

H8: Sağlık çalışanlarının liderlik eğitimi alıp almama durumlarına göre öz liderlik düzeyleri istatistiksel olarak anlamlı farklılıklar göstermektedir.

\subsection{Araştırmanın Evren ve Örneklemi}

Araştırma evrenini; Türkiye'de metropolitan alan içerisinde faaliyet gösteren, kamuya bağlı bir eğitim ve araştırma hastanesinde, 01-31 Mayıs 2017 tarihleri arasında fiili olarak çalışan tıbbi ve idari sağlık çalışanı oluşturmaktadır. Araştırmada veri elde etme aracı olarak anket yöntemi kullanılmıştır. Hastanede 752 hekim, 606 hemşire, 322 diğer sağlık personeli ve 131 idari personel ile toplamda 1811 sağlık çalışanı fiili olarak görev yapmaktadır. Araştırmada olasılıklı örnekleme yöntemlerinden biri olan tabakalı örnekleme yöntemi kullanılmıştır. Ulaşılması gereken örneklem büyüklüğü 318 olarak hesaplanmıştır. Bu örneklem tabakalara oranlanmış ve araştırma kapsamında, 132 hekim, 109 hemşire, 72 diğer sağlık personeli ve 44 idari personel olmak üzere 357 kişiye ulaşılmış ve analizler bu kişilerden elde edilen veriler üzerinden yapılmıştır.

\subsection{Veri Toplama Araci}

Çalışmada sağlık çalışanlarının öz liderlik düzeylerinin belirleyebilmek için $\ddot{O}_{z}$ Liderlik Ölçeği kullanılmıştır. Anderson ve Prussia (1997) tarafindan geliştirilen (SelfLeadership Questionnaire-SLQ) daha sonra Houghton ve Neck (2002) tarafindan doğrulayıcı çalışmaları yapılan Revize Edilmiş Öz Liderlik Ölçeği'nin (Revised SelfLeadership Questionnaire-RSLQ) Türkçe geçerlik ve güvenirliği Tabak vd. (2013) tarafından yapılmıştır. Ölçek 29 madde 3 alt boyut ve 8 bileşenden oluşmaktadır. Ölçek 1 (Kesinlikle Katılmıyorum) ve 5 (Kesinlikle Katılıyorum) arasında değerler alan 5'li Likert tipi ölçek türündedir. Ölçeğin alt boyutları davranış odaklı stratejiler, doğal ödül stratejileri ve yapıcı düşünce modeli stratejileri altında değerlendirilmektedir. Davranış odaklı stratejiler boyutu altında; kendini ödüllendirme, kendini cezalandırma, kendini gözlemleme, hatırlatıcılar belirleme bileşenleri bulunmaktadır. Doğal ödül stratejileri altında; doğal ödüller üzerine düşünceyi odaklama bileşeni yer almaktadır. Yapıcı düşünce modeli stratejisi altında, kendi kendine konuşma, düşünce ve fikirlerini değerlendirme, kendine hedef belirleyerek başarılı performans hayal etme bileşenleri mevcuttur.

\subsection{Araştırmanın Kısıtlılıkları}

$\mathrm{Bu}$ çalışma Ankara'da faaliyet gösteren bir eğitim ve araştırma hastanesinde görev yapan sağlık çalışanları üzerinden gerçekleştirilmiştir. Çalışmanın verileri bu popülasyon üzerinden elde edilen örneklemden elde edildiği ve analizlerde bu örneklem üzerinden gerçekleştirildiği için tüm sağlık çalışanlarına genellenemez. 


\subsection{Verilerin Analizi}

Araştırma analizleri SPSS (Statistical Package for the Social Sciences) 21.0 kullanılarak gerçekleştirilmiştir. Öncelikle, araştırmaya katılan sağlık çalışanlarının sosyo-demografik özellikleriyle ilgili tanımlayıcı bulguları ortaya koymak için frekans ve yüzdelerden faydalanılmıştır. Sağlık çalışanlarının öz liderlik alt boyutlarıyla ilgili değerlendirmelerinin sosyo-demografik özelliklere göre farklılaşıp farklılaşmadığını ortaya koymak amacıyla iki ortalama arasındaki farkın önemlilik testi (Standart $t$ testi) ve tek yönlü varyans analizi (F testi-ANOVA) kullanılmıştır. Gruplar arasında anlamlı farklılıklar bulunması durumunda anlamlılığın hangi gruptan kaynaklandığını bulmak amaciyla Post-hoc testlerinden biri olan Tukey HSD testinden faydalanılmıştır.

\section{Bulgular}

$\mathrm{Bu}$ çalışmanın tanımlayıcı ve hipotezlerine yönelik bulgular aşağıdaki tablolarda sunulmuştur.

\subsection{Tanımlayıcı Bulgular}

Tablo 1'de araştırmaya katılan sağlık çalışanlarına ilişkin tanımlayıcı bulgular sunulmuştur.

Tablo 1. Araştırmaya Katılan Sağlık Çalışanlarının Tanımlayıcı Özellikleri

\begin{tabular}{|c|c|c|c|}
\hline \multicolumn{2}{|r|}{ Değişkenler } & \multirow{2}{*}{$\begin{array}{l}\text { Sayı } \\
242\end{array}$} & \multirow{2}{*}{$\begin{array}{r}\% \\
67,8\end{array}$} \\
\hline Cinsiyet & Kadın & & \\
\hline & Erkek & 115 & 32,2 \\
\hline & $\leq 34$ & 197 & 55,2 \\
\hline Yaș & $\geq 35$ & 160 & 44,8 \\
\hline \multirow{2}{*}{ Medeni Durum } & Evli & 240 & 67,2 \\
\hline & Bekâr & 117 & 32,8 \\
\hline \multirow{4}{*}{ Eğitim Durumu } & $\begin{array}{c}\text { Lisans öncesi(İlköğretim, lise, } \\
\text { önlisans) }\end{array}$ & 103 & 28,9 \\
\hline & Lisans & 133 & 37,3 \\
\hline & Lisansüstü & 121 & 33,9 \\
\hline & Hekim & 132 & 37,0 \\
\hline Hastanedeki & Hemşire & 109 & 30,5 \\
\hline \multirow[t]{3}{*}{ Görev } & Diğ. Săg.Personeli & 72 & 20,2 \\
\hline & Idari Personel & 44 & 12,3 \\
\hline & $3000 T L$ altı & 110 & 30,8 \\
\hline \multirow[t]{2}{*}{ Gelir } & 3000-3999TL & 112 & 31,4 \\
\hline & 4000TL ve üzeri & 135 & 37,8 \\
\hline Sektörde & $\leq 10$ yll & 207 & 58,0 \\
\hline $\begin{array}{c}\text { Toplam } \\
\text { Çalıșma Süresi }\end{array}$ & $\geq 10 y l l$ & 150 & 42,0 \\
\hline Liderlik Eğitimi & Hayır & 256 & 71,7 \\
\hline Alıp Almama & Evet & 101 & 28,3 \\
\hline TOPLAM & & 357 & 100 \\
\hline
\end{tabular}

Tablo 1'de araştırmaya katılan sağlık çalışanlarının büyük bir bölümünün $(\% 67,8)$ kadınlardan oluştuğu görülmektedir. Yaş açısından bakıldığında; çalışanlarının \%55,2'sinin yaşının 34 yaş ve altında, \%44,8'inin de 35 ve üzeri yaşta olduğu görülmektedir. Sağlık çalışanlarının büyük bir bölümü $(\% 67,2)$ evli olduğunu belirtmiştir. Katılımcıların eğitim durumuna bakıldığında ise \%28,9'unun lisans öncesi (ilk ve orta öğretim, lise, ön lisans), \%37,3 lisans, \%33,9'unun lisansüstü dereceleri bulunmaktadır. Araştırmaya katılan sağlık çalışanlarının \%37'si hekimlerden oluşmaktadır. Sağlık çalışanlarının \%37,8'i gelirini 4000TL ve üzeri olarak ifade etmiştir. Katılımcıların sağlık sektöründe çalışma süresine bakıldığında, \%58' inin 10 yıl ve altında hizmet süresine sahip olduğu görülmektedir.
Katılımcıların önemli bir bölümü $(\% 71,7)$ liderlik konusunda herhangi bir eğitimi almadığını ifade etmiştir.

Tablo 2'de araştırmaya katılan sağlık çalışanlarının Öz Liderlik alt boyutlarına ilişkin Min.-Max., Ortalama ve Standart Sapma değerleri gösterilmektedir.

Tablo 2. Araştırma Katılan Sağlık Çalışanlarının Öz Liderlik Alt Boyutlarına İlișkin Min.-Max., Ortalama ve Standart Sapma Değerleri

\begin{tabular}{lllll}
\hline Değişkenler & Min. & Max. & Ort. & SS \\
\hline Kendini Ödüllendirme & 1,00 & 5,00 & 3,29 & 1,00 \\
Kendini Cezalandirma & 1,00 & 5,00 & 3,10 & 0,81 \\
$\begin{array}{l}\text { Kendini Gözlemleme } \\
\text { Hatırlatıc Belirleme }\end{array}$ & 1,00 & 5,00 & 3,89 & 0,65 \\
$\begin{array}{l}\text { Doğal Ödül Üzerine } \\
\text { Düşünceyi Odaklama }\end{array}$ & 1,00 & 5,00 & 3,29 & 1,02 \\
$\begin{array}{l}\text { Kendi Kendine Konuşma } \\
\text { Düsünce ve Fikirlerini }\end{array}$ & 1,00 & 5,00 & 3,80 & 0,77 \\
$\begin{array}{l}\text { Değerlendirme } \\
\text { Hedef Belirleyerek }\end{array}$ & 1,00 & 5,00 & 3,24 & 0,93 \\
$\begin{array}{l}\text { Başarll } \quad \text { Performans } \\
\text { Hayal Etme }\end{array}$ & & 5,00 & 3,89 & 0,56 \\
\hline
\end{tabular}

Tablo 2'de araştırmaya katılan sağlık çalışanlarının öz liderlik alt boyutlarına ilişkin minimum, maksimum, ortalama ve standart sapma değerleri bulunmaktadır. Buna göre sağlık çalışanlarının öz liderlik alt boyutları içerisinde en yüksek ortalamayı kendini gözlemleme $(3,89 \pm 0,65)$, düşünce ve fikirlerini değerlendirme $(3,89 \pm 0,56)$ ve doğal ödül üzerine düşünceyi odaklama $(3,80 \pm 0,77)$ bileşenlerine verdikleri görülmektedir. En düşük ortalamayı ise, kendini cezalandırma $\quad(3,10 \pm 0,81)$, kendini ödüllendirme $(3,29 \pm 1,00)$, hatırlatıcı belirleme $(3,29 \pm 1,02)$ alt boyutları almaktadir.

\subsection{Hipotezlere İlişkin Bulgular}

Aşağıdaki tablolarda araştırmaya katılan sağlık çalışanlarının; sosyo-demografik özelliklerine (cinsiyet, yaş, medeni durum, eğitim durumu, hastanedeki görev, gelir, sektörde çalışma süresi ve liderlik eğitimi alıp almama) göre öz liderlik bileşenlerine ilişkin değerlendirmeleri yer almaktadır.

Tablo 3. Araştırmaya Katılan Sağlık Çalışanlarının Cinsiyetlerin Göre Öz Liderlik Alt Boyutlarına İlişkin Skorları

\begin{tabular}{|c|c|c|c|c|c|c|}
\hline \multirow{3}{*}{$\begin{array}{l}\text { Öz Liderlik Alt } \\
\text { Boyutları }\end{array}$} & \multicolumn{4}{|c|}{ Cinsiyet } & \multirow{3}{*}{$\mathbf{t}$} & \multirow{3}{*}{$\mathbf{p}$} \\
\hline & \multicolumn{2}{|c|}{ Kadın } & \multicolumn{2}{|c|}{ Erkek } & & \\
\hline & Ort. & SS & Ort. & SS & & \\
\hline $\begin{array}{l}\text { Kendini } \\
\text { Ödüllendirme }\end{array}$ & 3,25 & 1,01 & 3,35 & 0,06 & $-0,844$ & 0,399 \\
\hline $\begin{array}{l}\text { Kendini } \\
\text { Cezalandırma }\end{array}$ & 3.15 & 0,79 & 3.00 & 0,85 & 1,594 & 0,112 \\
\hline $\begin{array}{l}\text { Kendini } \\
\text { Gözlemleme }\end{array}$ & 3,91 & 0,61 & 3,85 & 0,70 & 0,854 & 0,393 \\
\hline $\begin{array}{l}\text { Hatırlatıcı } \\
\text { Belirleme } \\
\text { Doğal Ödül }\end{array}$ & 3,31 & 1,01 & 3,26 & 1,04 & 0,406 & 0,685 \\
\hline $\begin{array}{l}\text { Üzerine } \\
\text { Düsünceyi } \\
\text { Odaklama }\end{array}$ & 3,83 & 0,77 & 3,72 & 0,76 & 1,329 & 0,185 \\
\hline $\begin{array}{l}\text { Kendi Kendine } \\
\text { Konuşma }\end{array}$ & 3,25 & 0,95 & 3,24 & 0,88 & 0,044 & 0,965 \\
\hline $\begin{array}{l}\text { Düşünce ve } \\
\text { Fikirleri } \\
\text { Değerlendirme }\end{array}$ & 3,94 & 0,56 & 3,79 & 0,57 & 2,307 & $0,022 *$ \\
\hline
\end{tabular}


Hedef

Belirleyerek

Başarll

3,63

0,69

3,67

0,74

$-0,489$

0,625

Performans

Hayal Etme

Tablo 3'te araştırmaya katılan sağlık çalıșanlarının öz liderlik alt boyutlarına ilişkin ortalamalarını cinsiyetlerine göre karşılaştıran t-testi sonuçları bulunmaktadır. Yapılan analiz sonucunda, öz liderlik alt boyutlarından biri olan düşünce ve fikirleri değerlendirme alt boyutuna ilișkin ortalamaların gruplar arasında istatistiksel olarak anlamlı bir şekilde farklılaştığı görülmektedir $(\mathrm{t}=2,307 ; \mathrm{p}<0,05)$. Kadınların $(3,94 \pm 0,56)$ düşünce ve fikirleri değerlendirme ortalamaları erkeklere $(3,79 \pm 0,57)$ göre daha yüksektir. Cinsiyet değişkeni açısından öz liderliğin diğer alt boyutlarına göre istatistiksel açıdan anlamlı bir fark bulunmadığ1 görülmektedir. Dolayısıyla kurulan H1 hipotezi öz liderliğin düşünce ve fikirlerini değerlendirme alt boyutu için kabul edilmiş, diğer boyutları için reddedilmiştir.

Tablo 4. Araştırmaya Katılan Sağlık Çalışanlarının Yaşlarına Göre Öz Liderlik AIt Boyutlarına İlişkin Skorları

\begin{tabular}{|c|c|c|c|c|c|c|}
\hline \multirow{3}{*}{$\begin{array}{l}\text { Öz Liderlik Alt } \\
\text { Boyutları }\end{array}$} & \multicolumn{4}{|c|}{ Yaş } & \multirow{3}{*}{$\mathbf{t}$} & \multirow{3}{*}{$\mathbf{p}$} \\
\hline & \multicolumn{2}{|c|}{$\leq 34$} & \multicolumn{2}{|c|}{$\geq 35$} & & \\
\hline & Ort. & SS & Ort. & SS & & \\
\hline $\begin{array}{l}\text { Kendini } \\
\text { Ödüllendirme }\end{array}$ & 3,48 & 0,95 & 3,05 & 1,02 & 4,087 & $<0,001 *$ \\
\hline $\begin{array}{l}\text { Kendini } \\
\text { Cezalandirma }\end{array}$ & 3,13 & 0,79 & 3,07 & 0,84 & 0,763 & 0,446 \\
\hline $\begin{array}{l}\text { Kendini } \\
\text { Gözlemleme }\end{array}$ & 3,79 & 0,67 & 4,02 & 0,61 & $\begin{array}{l}- \\
3,243\end{array}$ & $<0,001 *$ \\
\hline $\begin{array}{l}\text { Hatırlatıcı } \\
\text { Belirleme }\end{array}$ & 3,26 & 1,03 & 3,33 & 1,01 &,- 642 & 0,521 \\
\hline $\begin{array}{l}\text { Doğal Ödül } \\
\text { Üzerine Düşünceyi } \\
\text { Odaklama }\end{array}$ & 3,75 & 0,81 & 3,85 & 0,71 & $\overline{1}, 142$ & 0,254 \\
\hline $\begin{array}{l}\text { Kendi Kendine } \\
\text { Konuşma }\end{array}$ & 3,30 & 0,93 & 3,17 & 0,92 & 1,377 & 0,169 \\
\hline $\begin{array}{l}\text { Düşünce ve } \\
\text { Fikirlerini } \\
\text { Değerlendirme }\end{array}$ & 3,85 & 0,61 & 3,94 & 0,50 & $-\overline{1,490}$ & 0,137 \\
\hline $\begin{array}{l}\text { Hedef Belirleyerek } \\
\text { Başarll } \\
\text { Performans Hayal } \\
\text { Etme }\end{array}$ & 3,69 & 0,71 & 3,59 & 0,70 & 1,245 & 0,214 \\
\hline
\end{tabular}

Tablo 4'te araştırmaya katılan sağlık çalışanlarının öz liderlik alt boyutlarına ilişkin ortalamalarını yaşlarına göre karşılaştıran t-testi sonuçları gösterilmektedir. Analiz sonuçlarına bakıldığında; kendini ödüllendirme $(\mathrm{t}=4,087$, $\mathrm{p}<0,01)$ ve kendini gözlemleme $(\mathrm{t}=-3,243$; $\mathrm{p}<0,01)$ alt boyutlarına ilişkin ortalamaların yaşa göre istatistiksel olarak anlamlı şekilde farklılaştığı görülmektedir. Diğer alt boyutlara ilişkin ortalamaların katılımcıların yaşlarına göre istatistiksel olarak anlamlı bir şekilde farklılık göstermediği görülmektedir. Buna göre, 34 yaş ve altındaki katılımcıların kendini ödüllendirme $(3,48 \pm 0,95)$ alt boyutuna ilişkin ortalamaları 35 yaş ve üzerindeki katılımcıların ortalamalarına $(3,05 \pm 1,02)$ göre daha yüksek iken 35 yaş ve üzeri katılımcıların kendini gözlemleme $(4,02 \pm 0,61)$ alt boyutuna ilişkin ortalamaları 34 yaş ve altındaki katılımcıların ortalamalarına $(3,79 \pm 0,67)$ göre daha yüksektir. Dolayısıyla kurulan $\mathrm{H} 2$ hipotezi kendini ödüllendirme ve kendini gözlemleme alt boyutları için kabul edilmiş, diğer boyutlar için reddedilmiştir.
Tablo 5. Araştırmaya Katılan Sağlık Çalışanlarının Medeni Durumlarına Göre Öz Liderlik Alt Boyutlarına İlişkin Skorları

\begin{tabular}{|c|c|c|c|c|c|c|}
\hline \multirow{3}{*}{ 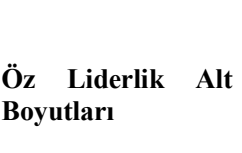 } & \multicolumn{4}{|c|}{ Medeni Durum } & \multirow{3}{*}{$\mathbf{t}$} & \multirow{3}{*}{$\mathbf{p}$} \\
\hline & \multicolumn{2}{|c|}{ Evli } & \multicolumn{2}{|c|}{ Bekâr } & & \\
\hline & Ort. & SS & Ort. & SS & & \\
\hline $\begin{array}{l}\text { Kendini } \\
\text { Ödüllendirme }\end{array}$ & 3,21 & 1,00 & 3,44 & 1,01 & 2,059 & $0,040 *$ \\
\hline $\begin{array}{l}\text { Kendini } \\
\text { Cezalandırma }\end{array}$ & 3,09 & 0,82 & 3,13 & 0,81 &,- 363 & 0,717 \\
\hline $\begin{array}{l}\text { Kendini } \\
\text { Gözlemleme }\end{array}$ & 3,90 & 0,66 & 3,88 & 0,65 & 0,339 & 0,735 \\
\hline $\begin{array}{l}\text { Hatırlatıcı } \\
\text { Belirleme }\end{array}$ & 3,24 & 1,03 & 3,39 & 1,00 & $\begin{array}{c}- \\
1,300\end{array}$ & 0,194 \\
\hline $\begin{array}{l}\text { Doğal Ödül Üzerine } \\
\text { Düşünceyi } \\
\text { Odaklama }\end{array}$ & 3,78 & 0,75 & 3,82 & 0,79 & $\begin{array}{c}- \\
0,430\end{array}$ & 0,668 \\
\hline $\begin{array}{l}\text { Kendi Kendine } \\
\text { Konuşma }\end{array}$ & 3,23 & 0,94 & 3,28 & 0,92 & $\begin{array}{c}- \\
0,504\end{array}$ & 0,614 \\
\hline $\begin{array}{l}\text { Düşünce ve } \\
\text { Fikirlerini } \\
\text { Değerlendirme }\end{array}$ & 3,88 & 0,55 & 3,91 & 0,60 & $\begin{array}{c}- \\
0,456\end{array}$ & 0,649 \\
\hline $\begin{array}{l}\text { Hedef Belirleyerek } \\
\text { Başarll Performans } \\
\text { Hayal Etme }\end{array}$ & 3,60 & 0,69 & 3,73 & 0,74 & 1,559 & 0,120 \\
\hline
\end{tabular}

Tablo 5'te araștırmaya katılan sağlık çalışanlarının öz liderlik alt boyutlarına ilişkin ortalamalarını medeni durumlarına göre karşılaştıran t-testi sonuçları gösterilmektedir. Analiz sonuçlarına bakıldığında; kendini ödüllendirme alt boyutuna ilişkin ortalamaların medeni durum açısından istatistiksel olarak anlamlı olduğu görülmektedir $\quad(\mathrm{t}=-2,059 ; \quad \mathrm{p}<0,05)$. Bekâr sağlık çalışanlarının kendini ödüllendirme ortalamalarının $(3,44 \pm 1,01)$ evli sağlık çalışanlarının kendini ödüllendirme ortalamalarından $(3,21 \pm 1,00)$ yüksek olduğu görülmektedir. Diğer alt boyutlara ilişkin ortalamaların medeni durum açısından istatistiksel olarak anlamlı olmadığı görülmektedir. Dolayısıyla kurulan $\mathrm{H} 3$ hipotezi kendini ödüllendirme alt boyutu için kabul edilmiş, diğer boyutlar için reddedilmiştir.

Tablo 6. Araștırmaya Katılan Sağlık Calıșanlarının Eğitim Durumlarına Göre Öz Liderlik Alt Boyutlarına İlişkin Skorları

\begin{tabular}{|c|c|c|c|c|c|c|c|c|}
\hline \multirow{3}{*}{$\begin{array}{lr}\text { Öz } & \text { Liderlik } \\
\text { Alt } & \text { Boyutları } \\
\text { ve } & \text { Diğer } \\
\text { Değișkenler }\end{array}$} & \multicolumn{4}{|c|}{ Eğitim Durumu } & & & \multirow{3}{*}{$\mathbf{F}$} & \multirow{3}{*}{$\mathbf{p}$} \\
\hline & \multicolumn{2}{|c|}{$\begin{array}{l}\text { Lisans } \\
\text { öncesi } \\
\end{array}$} & \multicolumn{2}{|c|}{ Lisans } & \multicolumn{2}{|c|}{ Lisansüstü } & & \\
\hline & Ort. & SS & Ort. & SS & Ort. & SS & & \\
\hline $\begin{array}{l}\text { Kendini } \\
\text { Ödüllendirme }\end{array}$ & 3,19 & 1,09 & 3,25 & 0,98 & 3,41 & 0,95 & 1,451 & 0,236 \\
\hline $\begin{array}{l}\text { Kendini } \\
\text { Cezalandirma }\end{array}$ & 3,11 & 0,85 & 3,12 & 0,75 & 3,08 & 0,85 & 0,088 & 0,916 \\
\hline $\begin{array}{l}\text { Kendini } \\
\text { Gözlemleme }\end{array}$ & 3,87 & 0,73 & 3,88 & 0,61 & 3,92 & 0,63 & 0,208 & 0,812 \\
\hline $\begin{array}{l}\text { Hatırlatıcı } \\
\text { Belirleme } \\
\text { Doğal Ödül }\end{array}$ & 3,30 & 1,08 & 3,31 & 1,00 & 3,27 & 0,99 & 0,058 & 0,944 \\
\hline $\begin{array}{l}\text { Üzerine } \\
\text { Düsünceyi } \\
\text { Odaklama }\end{array}$ & 3,83 & 0,81 & 3,78 & 0,78 & 3,79 & 0,72 & 0,115 & 0,891 \\
\hline $\begin{array}{l}\text { Kendi Kendine } \\
\text { Konuşma }\end{array}$ & 3,21 & 0,93 & 3,32 & 0,90 & 3,19 & 0,96 & 0,706 & 0,494 \\
\hline $\begin{array}{l}\text { Düsünce ve } \\
\text { Fikirlerini } \\
\text { Değerlendirme }\end{array}$ & 3,83 & 0,64 & 3,91 & 0,58 & 3,93 & 0,47 & 0,926 & 0,397 \\
\hline $\begin{array}{l}\text { Hedef } \\
\text { Belirleyerek } \\
\text { Başarllı }\end{array}$ & 3,60 & 0,75 & 3,68 & 0,66 & 3,65 & 0,71 & 0,460 & 0,632 \\
\hline
\end{tabular}


Performans

Hayal Etme

Tablo 6'da araştırmaya katılan sağlık çalışanlarının öz liderlik alt boyutlarına ilişkin ortalamalarını eğitim durumuna göre karşılaştıran ANOVA testi sonuçları gösterilmektedir. Analiz sonuçlarına bakıldığında; sağlık çalışanlarının öz liderlik alt boyutlarına ilişkin tüm ortalamalarının birbirine oldukça yakın olduğu ve eğitim durumuna göre gruplar arasındaki istatistiksel olarak anlamlı bir fark olmadığı görülmektedir $(\mathrm{p}>0,05)$. Dolayısıyla, kurulan $\mathrm{H} 4$ reddedilmiştir.

Araştırmaya katılan sağlık çalışanlarının öz liderlik alt boyutlarına ilişkin ortalamalarını hastanedeki görevlerine göre karşılaştıran ANOVA testi sonuçları Tablo 7'de yer almaktadır. Analiz sonuçlarına göre gruplar arasında istatistiksel olarak anlamlı farklılıklar görülmektedir. Katılımcıların kendini ödüllendirme $(F=7,239 ; \mathrm{p}<0,05)$, kendini gözlemleme $(F=3,155 ; p<0,05)$ ve hedef belirleyerek başarılı performans hayal etme $(\mathrm{F}=3,286$; $\mathrm{p}<0,05)$ alt boyutlarına ilişkin ortalamaları hastanedeki görevlerine göre istatistiksel olarak anlamlı farklılıklar göstermektedir.

İstatistiksel açıdan anlamlı farklılıkların ortaya çıktığı alt boyutlardaki farklılığın hangi gruptan kaynaklandığını tespit etmek için Post hoc testlerinden biri olan Tukey HSD testinden yararlanılmıştır. İdari personelin kendini ödüllendirme ortalamaları $(2,75 \pm 0,89)$ hekim ve hemşirelerin kendini ödüllendirme ortalamalarından $(3,52 \pm 0,89 ; 3,28 \pm 1,01)$ daha düşüktür $(p<0,05)$. Kendini gözlemleme alt boyutunda idari personelin $(3,61 \pm 0,75)$, diğer sağlık personeli $(3,95 \pm 0,71)$, hemşire $(3,94 \pm 0,60)$ ve hekim ortalamalarından $(3,92 \pm 0,61)$ düşük ortalamaya sahip görülmektedir. Son olarak hedef belirleyerek başarılı performans hayal etme alt boyutunda diğer sağlik personelinin ortalamaların $(3,37 \pm 0,80)$ diğer tüm gruplara oranla daha yüksek olduğu görülmektedir. Dolayısıyla, kurulan H5 hipotezi kendini ödüllendirme, kendini gözlemleme ve hedef belirleyerek başarılı performans hayal etme alt boyutları için kabul edilmiş, diğer alt boyutlar için ise reddedilmiştir.

Tablo 7. Araştırmaya Katılan Sağlık Çalışanlarının Hastanedeki Görevlerine Göre Öz Liderlik Alt Boyutlarına İlişkin Skorları

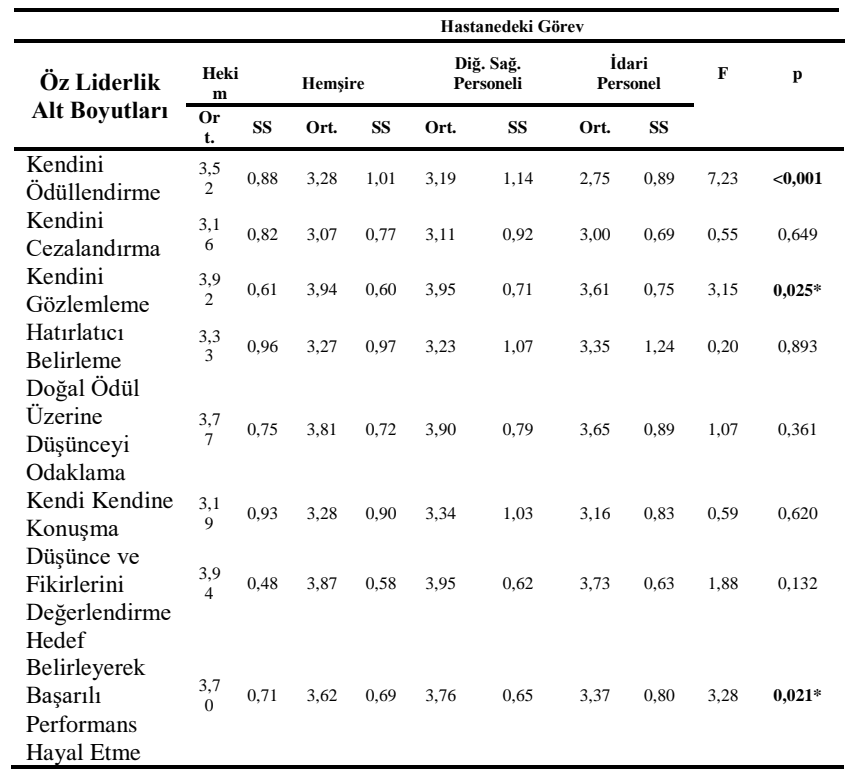

Araştırmaya katılan sağlık çalışanlarının öz liderlik alt boyutlarına ilişkin ortalamalarını gelirlerine göre karşılaştıran ANOVA testi sonuçları Tablo 8'de yer almaktadır. Analiz sonuçlarına göre; katılımcıların kendini ödüllendirme $(\mathrm{F}=4,310 ; \mathrm{p}<0,05)$, düşünce ve fikirlerini değerlendirme $(\mathrm{F}=3,189 ; \mathrm{p}<0,05)$ alt boyutlarına ilişkin ortalamalarının gelir durumlarına göre istatistiksel olarak anlamlı farklılıklar gösterdiği görülmektedir. Yapılan Tukey HSD testi sonuçlarına göre, gelirini 4000TL ve üzeri olarak beyan eden katılımcıların ortalamalarının hem kendini ödüllendirme hem de düşüncelerini değerlendirme alt boyutlarına ilişkin ortalamalarının diğer gruplara göre yüksek olduğu görülmektedir. Dolayısıyla, kurulan H6 hipotezi kendini ödüllendirme ve düşüncelerini değerlendirme alt boyutları için kabul edilmiş, diğer boyutlar için ise reddedilmiştir.

Tablo 8. Araştırmaya Katılan Sağlık Çalışanlarının Gelir Durumlarına Göre Öz Liderlik Alt Boyutlarına İliş̧in Skorları

\begin{tabular}{|c|c|c|c|c|c|c|c|c|}
\hline \multirow{3}{*}{$\begin{array}{l}\text { Öz Liderlik } \\
\text { Alt Boyutları }\end{array}$} & \multicolumn{4}{|c|}{ Gelir Durumu } & & & \multirow{3}{*}{$\mathbf{F}$} & \multirow{3}{*}{$\mathbf{p}$} \\
\hline & \multicolumn{2}{|c|}{$\begin{array}{l}\text { 3000TL } \\
\text { ve altı }\end{array}$} & \multicolumn{2}{|c|}{ 3000-3999TL } & \multicolumn{2}{|c|}{$\begin{array}{l}\text { 4000TL ve } \\
\text { üzeri }\end{array}$} & & \\
\hline & Ort. & SS & Ort. & SS & Ort. & SS & & \\
\hline $\begin{array}{l}\text { Kendini } \\
\text { Ödüllendirme }\end{array}$ & 3,20 & 1,02 & 3,14 & 1,07 & 3,48 & 0,90 & 4,310 & $0,014 *$ \\
\hline $\begin{array}{l}\text { Kendini } \\
\text { Cezalandırma }\end{array}$ & 3,03 & 0,88 & 3,09 & 0,76 & 3,18 & 0,81 & 1,041 & 0,354 \\
\hline $\begin{array}{l}\text { Kendini } \\
\text { Gözlemleme }\end{array}$ & 3,78 & 0,75 & 3,96 & 0,61 & 3,93 & 0,60 & 2,554 & 0,079 \\
\hline $\begin{array}{l}\text { Hattrlatıcı } \\
\text { Belirleme } \\
\text { Doğgl Ödül }\end{array}$ & 3,25 & 1,05 & 3,25 & 1,08 & 3,36 & 0,95 & 0,515 & 0,598 \\
\hline $\begin{array}{l}\text { Dogal Odül } \\
\text { Üzerine } \\
\text { Düşünceyi } \\
\text { Odaklama }\end{array}$ & 3,86 & 0,87 & 3,78 & 0,68 & 3,76 & 0,75 & 0,562 & 0,571 \\
\hline $\begin{array}{l}\text { Kendi Kendine } \\
\text { Konuşma }\end{array}$ & 3,20 & 0,93 & 3,30 & 0,96 & 3,24 & 0,91 & 0,331 & 0,719 \\
\hline $\begin{array}{l}\text { Düsü̈nce ve } \\
\text { Fikirlerini }\end{array}$ & 3,78 & 0,66 & 3,96 & 0,56 & 3,93 & 0,47 & 3,189 & $0,042 *$ \\
\hline $\begin{array}{l}\text { Değerlendirme } \\
\text { Hedef } \\
\text { Belirleyerek }\end{array}$ & & & & & & & & \\
\hline $\begin{array}{l}\text { Başarll } \\
\text { Performans } \\
\text { Hayal Etme }\end{array}$ & 3,55 & 0,75 & 3,68 & 0,68 & 3,70 & 0,70 & 1,459 & 0,234 \\
\hline
\end{tabular}

Tablo 9. Araştırmaya Katılan Sağlık Çalışanlarının Toplam Çalışma Sürelerine Göre Öz Liderlik Alt Boyutlarına İlişsin Skorları

\begin{tabular}{|c|c|c|c|c|c|c|}
\hline \multirow{3}{*}{$\begin{array}{l}\text { Öz Liderlik Alt } \\
\text { Boyutları }\end{array}$} & \multicolumn{4}{|c|}{ Toplam Çalışama Süresi } & \multirow{3}{*}{$\mathbf{t}$} & \multirow{3}{*}{$\mathbf{p}$} \\
\hline & \multicolumn{2}{|c|}{$\leq 10$} & \multicolumn{2}{|c|}{$\geq 11$} & & \\
\hline & Ort. & SS & Ort. & SS & & \\
\hline $\begin{array}{l}\text { Kendini } \\
\text { Ödüllendirme }\end{array}$ & 3,46 & 0,95 & 3,04 & 1,02 & 3,946 & $<0,001 *$ \\
\hline $\begin{array}{l}\text { Kendini } \\
\text { Cezalandırma }\end{array}$ & 3,16 & 0,81 & 3,03 & 0,81 & 1,559 & 0,120 \\
\hline $\begin{array}{l}\text { Kendini } \\
\text { Gözlemleme }\end{array}$ & 3,83 & 0,68 & 3,98 & 0,61 & 2,032 & $0,043 *$ \\
\hline $\begin{array}{l}\text { Hatırlatıcı } \\
\text { Belirleme }\end{array}$ & 3,25 & 1,03 & 3,35 & 1,00 & 0,903 & 0,367 \\
\hline $\begin{array}{l}\text { Doğal Ödül } \\
\text { Üzerine Düşünceyi } \\
\text { Odaklama }\end{array}$ & 3,75 & 0,80 & 3,85 & 0,72 & $\stackrel{-}{1,214}$ & 0,225 \\
\hline $\begin{array}{l}\text { Kendi Kendine } \\
\text { Konuşma }\end{array}$ & 3,32 & 0,92 & 3,14 & 0,93 & 1,764 & 0,079 \\
\hline $\begin{array}{l}\text { Düşünce ve } \\
\text { Fikirlerini } \\
\text { Değerlendirme }\end{array}$ & 3,87 & 0,60 & 3,92 & 0,51 & $\begin{array}{c}0- \\
, 868\end{array}$ & 0,386 \\
\hline $\begin{array}{l}\text { Hedef Belirleyerek } \\
\text { Başartl } \\
\text { Performans Hayal } \\
\text { Etme }\end{array}$ & 3,69 & 0,71 & 3,59 & 0,70 & 1,316 & 0,189 \\
\hline
\end{tabular}


Araştırmaya katılan sağlık çalışanlarının öz liderlik alt boyutlarına ilişkin ortalamalarını sektördeki toplam çalışma sürelerine göre karşılaştıran t-testi sonuçları Tablo 9' da görülmektedir. Buna göre; katılımcıların kendini ödüllendirme $(\mathrm{t}=3,946 ; \mathrm{p}<0,01)$ ve kendini gözlemle $(\mathrm{t}=$ 2,032; $<<0,05)$ alt boyutlarına ilişkin ortalamaları sektördeki toplam çalışma sürelerine göre istatistiksel olarak farklılaşmaktadır $(\mathrm{p}<0,05)$. Sektörde 10 yıl ve altında çalışma süresi bulunan katılımcıların kendini ödüllendirme alt boyutuna ilişkin ortalamaları $(3,46 \pm 0,95), 11$ yıl ve üzeri çalışma süresi bulunan katılımcıların ortalamalarından $(3,04 \pm 1,02)$ daha yüksektir. Kendini gözlemle boyutunda ise sektörde 11 yıl ve üzeri çalışma süresi bulunan katılımcıların ortalamalarının $(3,98 \pm 0,61)$, sektörde 10 y1l ve altında çalışma süresi bulunan katılımcıların ortalamalarından $(3,83 \pm 0,68)$ daha yüksek olduğu görülmektedir. Dolayısıyla, H7 hipotezi kendini ödüllendirme ve kendini gözlemleme alt boyutları için kabul edilmiş, diğer boyutlar için ise reddedilmiştir.

Tablo 10. Araștırmaya Katılan Sağlık Çalışanlarının Liderlik Eğitimi Alıp Almama Durumlarına Göre Öz Liderlik Alt Boyutlarına İlişkin Skorları

\begin{tabular}{|c|c|c|c|c|c|c|}
\hline \multirow{3}{*}{$\begin{array}{c}\text { Öz Liderlik Alt } \\
\text { Boyutları }\end{array}$} & \multicolumn{4}{|c|}{$\begin{array}{c}\text { Liderlik Eğitimi Alıp } \\
\text { Almama } \\
\end{array}$} & \multirow{3}{*}{$\mathbf{t}$} & \multirow{3}{*}{$\mathbf{p}$} \\
\hline & \multicolumn{2}{|c|}{ Hayır } & \multicolumn{2}{|c|}{ Evet } & & \\
\hline & Ort. & SS & Ort. & SS & & \\
\hline Kendini Ödüllendirme & 3,22 & 1,03 & 3,45 & 0,91 & $1, \overline{9} 37$ & 0,054 \\
\hline Kendini Cezalandırma & 3,17 & 0,78 & 2,94 & 0,87 & 2,469 & $0,014 *$ \\
\hline Kendini Gözlemleme & 3,80 & 0,65 & 4,13 & 0,60 & $\begin{array}{c}- \\
4,346\end{array}$ & $<0,001 *$ \\
\hline Hatırlatıcı Belirleme & 3,20 & 1,01 & 3,53 & 1,01 & 2,842 & $0,005^{*}$ \\
\hline $\begin{array}{l}\text { Doğal Ödül Üzerine } \\
\text { Düşünceyi Odaklama }\end{array}$ & 3,73 & 0,76 & 3,97 & 0,75 & 2,652 & $0,008 *$ \\
\hline $\begin{array}{l}\text { Kendi Kendine } \\
\text { Konuşma }\end{array}$ & 3,23 & 0,92 & 3,28 & 0,94 & $0, \overline{-}$ & 0,638 \\
\hline $\begin{array}{l}\text { Düsü̈nce ve Fikirlerini } \\
\text { Değerlendirme }\end{array}$ & 3,85 & 0,56 & 3,99 & 0,57 & $\begin{array}{c}- \\
2,106\end{array}$ & $0,036 *$ \\
\hline $\begin{array}{l}\text { Hedef Belirleyerek } \\
\text { Başarll Performans } \\
\text { Hayal Etme }\end{array}$ & 3,57 & 0,71 & 3,84 & 0,66 & $\begin{array}{c}- \\
3,336\end{array}$ & $0,001 *$ \\
\hline
\end{tabular}

Tablo 10'da araştırmaya katılan sağlık çalışanlarının öz liderlik alt boyutlarına ilişkin ortalamalarını liderlik eğitimi alıp almama durumlarına göre karşılaştıran t-testi sonuçları bulunmaktadır. Analiz sonuçlarına göre; katılımcıların kendini cezalandırma $(\mathrm{t}=2,469 ; \quad \mathrm{p}<0,05), \quad$ kendini gözlemleme $(\mathrm{t}=-4,346 ; \mathrm{p}<0,05)$, hatırlatıc1 belirleme $(\mathrm{t}=$ $2,842 ; \mathrm{p}<0,05)$ doğal ödül üzerine düşünceyi odaklama $(\mathrm{t}=$ $2,652 ; \mathrm{p}<0,05)$, düşünce ve fikirlerini değerlendirme $(\mathrm{t}=-$ 2,106; $<<0,05)$, hedef belirleyerek başarılı performans hayal etme $(\mathrm{t}=-3,336 ; \quad \mathrm{p}<0,05)$ alt boyutlarına ilişkin ortalamalarının liderlik eğitimi alıp almamalarına göre istatistiksel olarak farklılaştığı bulunmuştur. Liderlik eğitimi aldığını belirten sağlık çalışanlarının, kendini cezalandırma alt boyutu hariç (bu stratejide liderlik eğitimine sahip olanların kendini daha az cezalandırması beklenir) diğer alt boyutlara yönelik ortalamalarının, liderlik eğitimi almayanlara göre daha yüksek olduğu Tablo 10'de görülmektedir. $\mathrm{Bu}$ sonuç, kurulan $\mathrm{H} 8$ hipotezinin kendini cezalandırma, kendini gözlemleme, hatırlatıcı belirleme, doğal ödül üzerine düşünceyi odaklama, düşünce ve fikirlerini değerlendirme, hedef belirleyerek başarılı performans hayal etme alt boyutları için kabul edilmesini sağlamaktadır.

\section{Tartışma ve Sonuç}

Bu çalışmada, sağlık çalışanlarının öz liderlik düzeylerini ortaya koymak ve öz liderlik düzeylerinin sosyo-demografik özelliklere göre farklılaşıp farklılaşmadığı araştırılmak istenmiştir. $\mathrm{Bu}$ kapsamda, Ankara metropolitan alan içerisinde faaliyet gösteren bir eğitim ve araştırma hastanesinde çalışmakta olan 357 sağlık çalışanıyla bu çalışma yürütülmüştür.

Elde edilen sonuçlara bakıldığında, sağlık çalışanlarının öz liderlik alt boyutları içerisinde en yüksek ortalamayı sırasıyla; kendini gözlemleme, düşünce ve fikirlerini değerlendirme ve doğal ödül üzerine düşünceyi odaklama stratejilerine verdikleri görülmektedir. En düşük ortalamayı ise, kendini cezalandırma, kendini ödüllendirme, hatırlatıcı belirleme stratejileri almaktadır. Bu bulgu literatürdeki diğer çalışmalar ile benzerlik göstermektedir. Kayral'ın (2015: 151) Gaziantep’te özel bir hastanenin 335 sağlık çalışanıyla gerçekleştirdiği çalışmada, kendini gözlemleme, doğal ödüller üzerine düşünceyi odaklama, düşünce ve fikirleri değerlendirme stratejilerinin ortalamalarının yüksek kendini cezalandırma, kendini ödüllendirme ve hatırlatıcı belirleme stratejilerinin ortalamalarının ise düşük olduğu görülmektedir. Savunma sanayinde 240 çalışan ile yapılan bir diğer araştırma sonucuna göre, kendini gözlemleme, düşünce ve fikirleri değerlendirme, doğal ödüller üzerine düşünceyi odaklama stratejilerinin ortalamaları yüksek iken, hatırlatıcı belirleme, kendini ödüllendirme ve kendini cezalandırma stratejileri ise en düşük ortalamalara sahiptir (Özsoy, 2012: 160). Arlı (2011: 105)'nın 7 farklı ilde 404 öğretmenle gerçekleştirdiği çalışmaya göre, katılımcıların öz liderlik algılarının en yüksek olduğu boyut kendini gözlemleme, en düşük olduğu boyut ise kendini cezalandırmadır. Sağlık sektörünün insan merkezli olması ve sağlık hizmet sunumunun dikkat isteyen bir çaba olmasından ötürü sağlık çalışanlarının kendilerini gözlemledikleri söylenebilir. Ayrıca karar verirken düşünceleri ve fikirlerini değerlendirmeyi de önemsedikleri ve işlerini yerine getirirken işten kaynaklı doğal ödüller üzerine odaklandıkları anlaşılmaktadır. Sağlık çalışanlarının kendilerini daha az cezalandırdıkları ve başarıları karşısında kendilerini daha az ödüllendirdikleri söylenebilir. Basit veya sembolik de olsa kendini ödüllendirme alışkanlığı edinmek motivasyon ve öz liderlik için önemlidir. Hatırlatıcı belirleme stratejisinde kişinin notlar, listeler, iş ajandaları, klinik karar destek sistemleri vb. şeyler kullanarak işi hakkında yapması gereken şeyleri unutmasını engelleyen yöntemlerin geliştirilmesi hedeflenir. Sağlık çalışanlarının bu stratejiye ilişkin ortalamalarının düşük olması onların daha az hatırlatıcı belirleme stratejisi uyguladıklarını göstermektedir. Dolayısıyla, katılımcıların kendini ödüllendirme, hatırlatıcı belirleme ve kendini cezalandırma stratejilerine yoğunlaşarak öz liderlik becerilerini geliştirebileceği söylenebilir.

Literatüre bakıldığında genel olarak, cinsiyet ve öz liderlik arasında bir ilişki bulunmadığı ifade edilmektedir (Kurman, 2001; Kazan, 1999). Bu çalışmada ise öz liderlik stratejilerinden biri olan düşünce ve fikirleri değerlendirme stratejisi ortalamalarının cinsiyete göre farklılık gösterdiği tespit edilmiştir. Özsoy (2012: 182)'un savunma sanayinde çalışan 240 çalışanla yürüttüğü çalışmasına göre, öz liderliğin cinsiyet açısından doğal ödüller üzerine odaklanma, davranış odaklı stratejiler ve yapıcı düşünce 
stratejileri boyutlarında farklılaştığını ortaya koymuştur. Öğretmenler üzerinde gerçekleştirilen bir başka çalışma sonucuna göre katılımcıların kendini ödüllendirme, kendini cezalandırma ve kendi kendine konuşma boyutlarına ilişkin ortalamaları cinsiyete göre farklılaştırmaktadır (Arlı, 2011: 110). Uğurluoğlu (2010: 186) çalışmasında, cinsiyet değişkeninin öz liderlik stratejilerinden olan yapıcı düşünce modeli stratejilerini yordayan bir değişken olduğunu ortaya koymuş ve kadın sağlık çalışanlarının erkek sağlık çalışanlarına göre öz liderlik stratejilerini kullanma olasılıklarının yüksek olduğunu tespit etmiştir. Literatür bulguları ile kısmen uyumlu olmasına rağmen kadın sağlık çalışanlarının düşünce ve fikirleri değerlendirme ortalamalarının erkeklere oranla daha yüksek olması kadın sağlık çalışanların ilgili boyutta daha çok öz liderlik becerisi sergiledikleri şeklinde yorumlanabilir. Kültürel farklılıklardan ötürü insanların davranış ve düşünce süreçleri birbirinden çok farklı olabilmektedir (D'Intino et al., 2007: 114). Dolayısıyla, bu bulgunun Türkiye'deki çalışmalar ve uluslararası alanda yapılan çalışmalarla farklılık göstermesinin nedeninin kültürel farklılıklardan kaynaklanabileceği söylenebilir.

$\mathrm{Bu}$ çalışmada da, öz liderlik stratejilerinden kendini ödüllendirme ve kendini gözlemleme yaşa göre farklılık göstermektedir. Kazan (1999)'ın Amerika'daki bir işletmenin 127 çalışanıyla gerçekleştirdiği çalışma sonucuna göre, yaş ve öz liderlik stratejileri arasında negatif yönlü bir ilişki bulmuştur. Bu durum, insanların yaşları yükseldikçe öz liderlik algılarının azaldığını ifade etmektedir. Bu çalışmada, 34 yaş ve altındaki katılımcıların kendini ödüllendirme alt boyutlarına ilişkin ortalamaları 35 yaş ve üzerindeki katılımcıların ortalamalarından yüksek iken ve 35 yaş ve üzerindeki katılımcıların kendini gözlemleme alt boyutuna ilişkin ortalamaları 34 yaş ve altındaki katılımcıların ortalamalarından daha yüksektir. Genç sağlık çalışanlarının kendini daha çok ödüllendirdikleri, ileri yaş grubuna sahip sağlık çalışanlarının ise kendilerini daha çok gözlemlediği görülmektedir. İleri yaş gurubunda olan sağlık çalışanlarının tecrübe, bilgi ve birikim sahibi olmaları; genç sağlık çalışanlarına oranla meslekte daha fazla çalışma sürelerine sahip oldukları göz önüne alındığında kendilerini daha fazla gözlemlemeleri gayet doğaldır.

Kazan (1999) çalışmasında, evli ve bekâr çalışanların öz liderlik düzeylerinde anlamlı bir fark olmadığını fakat çalışanların evlilik sürelerinin öz liderlik düzeyleri üzerinde istatistiksel olarak anlamlı bir fark olduğunu tespit etmiştir. Bu çalışmada, sağlık çalışanlarının, kendini ödüllendirme alt boyutuna ilişkin ortalamalarının medeni durum açısından istatistiksel olarak anlamlı şekilde farklılaştığ görülmektedir. Bekâr sağlık çalışanlarının kendini ödüllendirme ortalamaları evli sağlık çalışanlarının ortalamalarından yüksektir. $\mathrm{Bu}$ durum bekâr sağlık çalışanların ilgili alt boyutta öz liderlik algılarının daha yüksek olduğu ve başarılı durumlar karşısında kendilerini somut veya zihinsel bir şeyle ödüllendirdiklerini ortaya koymaktadir.

$\mathrm{Bu}$ çalışmada, öz liderlik alt boyutlarına ilişkin değerlendirmelerin katılımcıların eğitim durumuna göre farklılaşmadığı ortaya konulmuştur. Bu bulgu literatürdeki bir çalışmayla benzerlik göstermekte iken diğer çalışmalardan ise farklılaşmaktadır. Orhan (2012: 101) tarafından 274 sporcu ile yapılan çalışmada, öz liderlik boyutlarına ilișkin puanların sporcuların eğitim durumlarına göre değişmediği ortaya koyulmuştur. Diğer bazı çalışmalarda ise öz liderlik skorlarının eğitim durumuna göre farklılaştığı görülmektedir (Özsoy,2012; Arlı,2011; Türköz, 2010). Bu çalışmada, çalıșanların öz liderlik düzeylerinin katılımcıların eğitim durumlarına göre farklılaştığı tespit edilmiştir. Bunun nedenleri arasında bahsi geçen çalışmaların farklı sektörlerde (savunma, eğitim vb.) gerçekleştirilmiş olması gösterilebilir.

$\mathrm{Bu}$ çalışmada, idari personelin kendini ödüllendirme ortalamaları hekim ve hemşirelerin kendini ödüllendirme ortalamalarından daha düşük bulunmuştur. Ayrıca, kendini gözlemleme alt boyutunda idari personel ortalamalarının diğer sağlık personeli, hemşire ve hekim ortalamalarından düşük olduğu görülmektedir. Hedef belirleyerek başarılı performans hayal etme alt boyutunda ise diğer sağllk personelinin ortalamaların diğer tüm gruplara oranla daha yüksek olduğu görülmektedir. $\mathrm{Bu}$ durum öz liderlik düzeylerinin sağlık çalışanlarının hastanedeki görevlerine göre farklılaştığını göstermektedir. Bu bulgu literatürdeki diğer çalışmalarla benzerlik göstermektedir. Türköz'ün (2010: 156) çalışmasında, çalışanların görevlerine göre (alt kademe yönetici, orta kademe yönetici, üst kademe yönetici) öz liderlik düzeylerinin farklılaştığı ortaya konmuştur. Benzer şekilde, Orhan (2012: 102-103) tarafindan gerçekleştirilen çalışma bulguları da öz liderliğin katılımcıların görevlerine (subay, astsubay, askeri öğrenci vb.) göre farklılık gösterdiğini ortaya koymaktadır.

Gelirini 4000TL ve üzeri olarak beyan eden sağlık çalışanlarının hem kendini ödüllendirme hem de düşüncelerini değerlendirme alt boyutlarına ilişkin ortalamalarının diğer gelir gruplara göre daha yüksek olduğu görülmektedir. Geliri yüksek katılımcıların kendisini ödüllendirme ve kendisini gözlemleme düzeyi daha yüksektir. $\mathrm{Bu}$ durum öz liderlik düzeyinin gelire göre değişebileceğini göstermektedir. Nitekim geliri yüksek çalışanların başarıları karşısında kendilerini daha çok ödüllendirebilecekleri (kendilerini maddi şeylerle ödüllendirebilecek finansal imkânları olduğundan) ve genellikle yüksek gelire sahip olan grubun hekimler olduğu düşünülürse yaptıkları işleri hassasiyetle yerine getirmeleri gerektirdiğinden düşünce ve fikirlerini de dikkatle değerlendirdikleri söylenebilir.

Sektörde 10 yıl ve altında çalışma süresi bulunan katılımcıların kendini ödüllendirme alt boyutuna ilişkin ortalamaları, 11 yıl ve üzeri çalışma süresi bulunan katılımcıların ortalamalarından daha yüksektir. Kendini gözlemle boyutunda ise sektörde 11 y1l ve üzeri çalışma süresi bulunan katılımcıların ortalamalarının, sektörde 10 yıl ve altında çalışma süresi bulunan katılımcıların ortalamalarından daha yüksek olduğu görülmektedir. Bu bulgu literatürdeki diğer çalışmalarla benzerlik göstermektedir. Arlı'nın (2011) çalışmasına göre, öğretmenlerin çalışma süreleri arttıkça kendini ödüllendirme, kendi kendine konuşma ile düşünce ve fikirleri değerlendirme davranışlarını sergileme eğilimleri artırmaktadır. Özsoy (2012) çalışmasına göre de yapıcı düşünce modeli stratejileri toplam çalışma süresine göre farklılaşmaktadır.

$\mathrm{Bu}$ çalışmada, liderlik eğitimi aldığını belirten sağlık çalışanlarının, kendini gözlemleme, hatırlatıcı belirleme, doğal ödül üzerine düşünceyi odaklama, düşünce ve fikirleri 
değerlendirme, hedef belirleyerek başarılı performans hayal etme alt boyutlarına ilişkin ortalamalarının liderlik eğitimi almayanlara göre daha yüksek olduğu ortaya koyulmuştur. $\mathrm{Bu}$ bulgu literatür ile benzerlik göstermektedir. Uğurluoğlu'nun (2010: 184) çalışmasında, liderlik konusunda herhangi bir eğitim almayan çalışanların davranış odaklı stratejileri, doğal ödül stratejilerini, yapıcı düşünce modeli stratejilerini kullanma olasılıkları, liderlik eğitimi alan çalışanlara göre daha azdır. Uğurluoğlu vd.' nin (2015) Kırıkkale Devlet Hastanesinde çalışan 450 sağlık çalışanıyla yürüttüğü çalışmalarının analiz sonuçlarına göre, liderlik eğitimi alanların öz liderlik stratejilerini daha fazla sergiledikleri ortaya koyulmuştur. Benzer şekilde bu çalışmada da liderlik eğitimi aldığını beyan eden sağlık çalışanlarının öz liderlik stratejileri ortalamalarının genel olarak daha yüksek olduğu görülmektedir.

Araştırma sonuçlarına dayalı olarak sağlık çalışanları ve yöneticilerine aşağıdaki önerilerde de bulunulabilir:

-Sağlık çalışanlarına notlar, listeler, iş ajandası, klinik karar destek sistemleri vb. gibi hatırlatıcılar kullanarak hatırlatıcı belirleme stratejisini aktif bir şekilde kullanmaları önerilir. Başarılı eylemlerini ödüllendirmeleri öz liderlik düzeylerinin artırılmasını sağlayacaktır. Ayrıca hatalardan ders çıkarılmalı, başarısızlık/hatalar karşısında kendilerini cezalandırmaları önerilir. Örneğin, sağlık çalışanın yaptığı tıbbi hata karşında kendisine kızarak motivasyonunu doğru yere kanalize etmesi sağlanabilir ve hataların tekrar edilmesinden kaçınılabilir.

-Sağlık hizmet sunumunun dikkat isteyen bir çaba olması sağlık çalışanlarının dikkatli davranmalarını, iyi birer gözlemci olmalarını gerektirir. Bu bağlamda, tüm öz liderlik stratejilerinin içselleştirilmesi fakat kendi gözlemleme stratejisine daha fazla önem verilmesi önerilir. Ayrıca sağlık çalışanlarının bir müdahale veya bir eylemde bulunmadan önce düşünce ve fikirlerini değerlendirmelerinin kendilerine önemli katkılar sunacağı söylenebilir. Sağlık bakım hizmetlerinde kalitenin artırılması için sağlık çalışanlarının her eylemlerini, her adımlarını atarken düşünce ve fikirlerini değerlendirerek bu adımları atmaları önerilir.

-Evli ve yaşça büyük olan sağlık çalışanlarının genç sağlık çalışanlarına göre daha az öz liderlik düzeylerine sahip olduğu, kendilerini daha az ödüllendirdikleri görülmektedir. $\mathrm{Bu}$ grubun öz liderlik becerilerini geliştirecek zihinsel ve davranışsal stratejiler geliştirmeleri, başarıları karşısında kendilerini daha fazla ödüllendirmeleri önerilir. Bu sağlık çalışanlarının öz liderlik becerilerinin geliştirilmesinde bazı örnekler katkı sağlayabilir. Örneğin, başarılarından ötürü tatile çıkılabilir, zihinsel olarak yeni başarılar imgelenebilir, kendisini zihinsel olarak tebrik edebilir. Başarıları karşısında motivasyonunu daha da artırabilecek iş ortamlarını yeniden dizayn edebilirler. Olumsuz düşünce ve fikirler ve içsel konuşmalara imkân vermeyebilirler ve kendilerine zaman ayırarak kendileri hakkında gözlemlerde bulunabilirler.

-Hastanedeki görevleri açısından değerlendirildiğinde, idari personelin öz liderlik düzeylerinin düşük olduğu görülmektedir. Sağlık yöneticilerinin bu grubun öz liderlik becerilerini geliştirmelerine olanak tanımalı bu konuda eğitimler vermeleri önerilir. Ayrıca idari personelin öz liderlik becerilerini geliştirecek stratejileri kullanmaları önerilir.
-Liderlik eğitiminin öz liderlik düzeyini artırdığı görülmektedir. Genel olarak liderlik, özel olarak ise öz liderlik eğitimlerinin sağlık yöneticileri tarafından teşvik edilmesi ve hastanenin eğitim biriminin düzenli aralıklarla bu eğitimleri düzenlemesi önerilir. Görüldüğü üzere, sağlık çalışanlarının öz liderlik düzeyleri sosyo-demografik özelliklerine göre farklılaşabilmektedir. $\mathrm{Bu}$ bağlamda, liderlik eğitimlerinin içeriğinin gruplara göre farklı tasarlanması gerekebilir. Bu konuda eğitim sorumlularının ve sağlık yöneticilerin güncel literatür bilgisi ve konuyla ilgili bilimsel sonuçlar 1şı̆̆ında, farklı gruplara yönelik eğitimler tasarlayabilmelidirler.

$\mathrm{Bu}$ araştırma sadece bir hastanede yapıldığından sonuçlarının genellenebilirliği açısından kısıtlarının olduğu ifade edilebilir. Gelecekte yapılacak çalışmaların kamu ve üniversite hastanelerinde yapılması ve bu hastanelerle benzer özelliklere sahip özel hastanelerle karşılaştırılmaları önerilmektedir. Bu çalışmada sadece öz liderliğin sosyodemografik özelliklerle olan ilişkisi test edilmiştir. Öz liderlikle ilgili çalışmaların kısıtlı olması gelecekte yapılacak çalışmaların özellikle de sağlık hizmetlerini temel alan çalışmaların alana ciddi katkılarının olabileceği söylenebilir. Gelecekte sağlık sektöründe yaratıcılık, iş özerkliği, psikolojik faktörler, inovasyon, performans, vb. farklı değişkenlerin öz liderlik ile ilişkilerini esas alan çalışmaların yapılması önerilmektedir.

\section{Kaynakça}

Alves, J. C., Lovelace, K. J., Manz, C. C., Matsypura, D., Toyasaki, F. \& Ke, K. (2006). A Cross-Cultural Perspective of Self-Leadership. Journal of Managerial Pyschology, 21 (4), 338-359.

Anderson, J. S., \& Prussia, G. E. (1997). The self-leadership questionnaire: Preliminary assessment of construct validity. Journal of Leadership and Organizational Studies, $\quad 4(2), \quad 119-143 . \quad$ DOI: 10.1177/107179199700400212

Arl1, Ö. (2011). Bazı Öncül ve Ardillarlyla Öz Liderlik: İlkögretim Öğretmenleri Üzerine Bir Araştırma. Yayınlanmamış Yüksek Lisans Tezi, Kara Harp Okulu: Ankara.

Bakan, İ. (2008). “Örgüt Kültürü” ve "Liderlik” Türlerine İlişkin Algılamalar İle Yöneticilerin Demografik Özellikleri Arasındaki İlişki: Bir Alan Araştırması. KMÜ IIBF Dergisi , 10 (14), 13-40.

Bligh, M. C., Pearce, C. L. \& Kohles, J. C. (2006). The Importance of Self-and Shared Leadership in Team Based Knowledge Work: A Meso-Level Model of Leadership Dynamics. Journal of Managerial Psychology, 21 (4), 296-318.

Byrant, A. \& Kazan, A. L. (2013). Self-Leadership How to Become a More Successful, Efficient, and Effective Leader from the Inside Out. NewYork: McGrawhill.

Carmelie, A., Meitar, R. \& Weisberg, J. (2006). SelfLeadership Skills and Innovative Behaviour at Work. International Journal of Manpower , 27 (1), 75-90.

Deci, E. L. \& Ryan, R. M. (1985). The Support of Autonomy and the Control of Behavior. Journal of Personality and Social Psychology, 53 (6), 1024-1037 
D'Intino, R. S., Goldsby, M. G., Houghton, J. D. \& Neck, C. P. (2007). Self-Leadership: A Process for Entrepreneurial Success. Journal of Leadership and Organizational Studies , 13 (4), 105-120.

DiLiello, T. C. \& Houghton, J. D. (2006). Maximizing Organizational Leadership Capacity for the Future: Toward A Model of Self-Leadership, Inovation and Creativity. Journal of Managerial Pyscology , 21 (4), 319-337.

Doğan, S. \& Şahin, F. (2008). Kendi Kendine Liderlik Ölçeğinin Türkçe Uyarlaması, Geçerlik ve Güvenirlik Çalışması. H. U. İktisadi ve İdari Bilimler Fakültesi Dergisi, 26 (1), 139-164.

Dolbier, C.L., Soderstrom, M. \& Steinhart, M.A. (2001). The Relationship Between Self- Leadership and Enhanced Pyschological, Health, and Work Outcomes. Journal of Psychology, 135(5).469-485.

Furtner, M. R., Rauthmann, J. F. \& Sachse, P. (2015). Unique Self-leadership: A Bifactor Model Approach. Leadership , 11 (1), 105-125.

Göksoy, S., Emen, E. \& Yenipınar, Ş. (2014). Öğretmenlerin Öz Liderlik Rolleri ile Örgütsel Vatandaşlık Arasındaki İlişkinin İncelenmesi. KSÜ Sosyal Bilimler Dergisi, 11 (1), 103-116.

Griffith J.R. (1998). Designing 21st Century Healthcare: Leadership in Hospitals and Healthcare Systems. Chicago, Ill: Health Administration Press.

Houghton, J. D. \& Jinkerson, D. L. (2007). Constructive Thought Strategies and Job Satisfaction: A Preliminary Examination. Journal of Business Psycology , 2007 (22), 45-53.

Houghton, J. D. \& Neck, C. P. (2002). The Revised SelfLeadership Questionnaire: Testing a Hierarchical Factor Structure for Self-Leadership. Journal of Managerial Pschology, 17 (8), 672-691.

Houghton, J. D., Dawley, D. \& DiLiello, T. C. (2012). The Abbreviated Self- Leadership Questionnaire (ASLQ): A More Concise Measure of Self- Leadership. International Journal of Leadership Studies , 7 (2), 216-232.

Houghton, J. D., Neck, C. P. \& Manz, C. C. (2003). SelfLeadership and Superleadership: The Heart and Art of Creating Shared Leadership in Teams. C. L. Pearce, ve J. A. Conger içinde, Shared Leadership: Reframing The Hows and Whys of Leadership (s. 123-140). Thousand Oaks, CA: Sage.

Kayral, İ. H. (2015). Öz liderlik Becerilerinin, Sağlık Çalışanlarının İş Tatminleri ve İş Performanslarına Etkisi. H.Ü Sağlık İdaresi Dergisi , 18 (2), 143-159.

Kazan, A. L. (1999). Exploring the Concept of SelfLeadership: Factors Impacting Self-Leadership of Ohio Americorps Members. Doktora Tezi, Ohio State Üniversity.Ohio.

Kurman, J. (2001). Self-Regulation Strategies in Achievement Setting: Culture and Gender Differences. Journal of Cross-Cultural Psychology, 32(4), 491-503.
Lovelace, K. J., Manz, C. C. \& Alves, J. C. (2007). Work Stress and Leadership Development: The Role of SelfLeadership, Shared Leadership, Physical Fitness and Flow in Managing Demands and Increasing Job Control. Human Resource Management Review , 17 (2007), 374387.

Manz, C. C. \& Sims, H. P. (2001). The New Superleadership Leading Others To Lead Themselves. San Francisco, California: Berrett-Koehler Publishers.

Manz, C. C. \& Sims, H. P. (1991). SuperLeadership: Beyond the Myth of Heroic Leadership. Organizational Dynamics, 19 (4), 18-35.

Manz, C. C. (1986). Self-Leadeship: Toward an Expanded Theory of Self Influence Process in Organization. Academy of Management Review, 11 (3), 585-600.

Manz, C. C. (1992). Mastering Self-Leadership: Empowering Yourself for Personal Excellence. PrenticeHall, Englewood Clifl"s, NJ

Manz, C. C., Houghton, J. D., Neck, C. P., Fugate, M. \& Pearce, C. (2016). Whistle While You Work: Toward Model of Emotional Self-Leadership. Journal ol Leadership and Organizational Studies, 23 (4), 374-386.

Nam Young, Yang \& Sun Young, Moon. (2001). Relationship of Self-leadership, Stress and Satisfaction in Clinical Practice of Nursing Students. J Korean Acad Nurs Admin, 17(2). 216-225

Neck, C. P. \& Houghton, J. D. (2006). Two Decades of SelfLeadership Theory and Research. Past Developments, Present Trends, and Future Possibilities. Journal of Managerial Psychology, 21(4), 270-295.

Neck, C. P. \& Milliman, J. F. (1994). Thought Selfleadership: Finding Spiritual Fulfilment in Organizational Life. Journal of Managerial Psychology, 9(6). 9-16. https://doi.org/10.1108/02683949410070151

Neubert, M. J. \& Ju-Chien, C. W. (2006). An Investigation of the Generalizability of the Houghton and Neck Revised Self-Leadership Questionnaire To A Chinese Context. Journal of Managerial Psychology, 21 (4), 360373.

Orhan, R. (2012). Oryantiring Sporcuların Kendi Kendine Liderlik Algıları. (Yayınlanmamış Yüksek Lisans Tezi). Kırıkkale Üniversitesi Sağlık Bilimleri Enstitüsü, Kırıkkale.

Özsoy, İ. (2012). Örgüt İklimi, Öz liderlik ve Işs Tatmininin Ar-Ge Performansına Etkisi. (Yayınlanmamış Doktora Tezi).Kara Harp Okulu Savunma Bilimleri Enstitüsü, Ankara.

Pearce, C. L. \& Manz, C. C. (2005). The New Silver Bullets of Leadership: The importance of Self- and Shared Leadersih in Knowledge Work. Organizational Dynamics, 34(2), 130-140.

Prussia, G. E., Anderson, J. S. \& Manz, C. C. (1988). SelfLeadership and Performance Outcomes: The Mediating Influence of Self-Efficacy. Journal of Organizational Behavior, 19 (1988), 523-538. 
Seunghye, Choi., Insun, Jang., Seungmi, Park. \& Haeyoung, Lee. (2014). Effects of Organizational Culture, SelfLeadership and Empowerment on Job Satisfaction and Turnover Intention in General Hospital Nurses. J Korean Acad Nurs Adm, 20(2). 206-2014.

Solà, Glòria Jodar i; Badia, Joan Gené i; Hito, Pilar Delgado; Osaba, M. Antonia Campo. \& García, Jose Luís Del Val. (2016). Self-Perception of Leadership Styles and Behaviour in Primary Health Care. BMC Health Services Research, 16(572).1-9. DOI 10.1186/s12913-016-18192

Tabak, A. Sığrı, Ü. \& Türköz, T. (2013). Öz Liderlik Ölçeğinin Türkçeye Uyarlanması Çalışması. Bilig (67), 213-246.

Türköz, T. (2010). Çalışanların Öz Liderlik Algısının İlenim Yönetimi Taktiklerini Kullanımlarına Olan Etkileri: Savunma Sanayinde Uygulamalı Bir Araştırma. (Yayınlanmamış Yüksek Lisans Tezi). Kara Harp Okulu Savunma Bilimleri Enstitüsü, Ankara.

Uğurluoğlu, Ö. (2010). Kendi Kendine Liderlik Stratejileri Üzerine Bir Araştırma. Atatürk Üniversitesi İktisadi ve Idari Bilimler Dergisi, 24(1).175-191.

Uğurluoğlu, Ö., Saygıll, M., Özer, Ö. \& Şantaş, F. (2015). Exploring The Impacts of Personal Factors on Self Leadership in A Hospital Setting. International Journal of Health Planning and Management, 30 (1), 3-13.

Uhl-Bien, M., Marion, R. \& McKelvey, B. (2007). Complexity Leadership Theory: Shifting leadership from the Industrial Age to the Knowledge Era. The Leadership Quarterly, 18 (4), 298-318.

Unsworth, K. L. \& Mason, C. M. (2012). Help Yourself: The Mechanisms Through Which A Self-Leadership Intervention Influences Strain. Journal of Occupational Health Psychology, 17(2), 235-245.

Watson, L. (2004). Self-Leadership: Becoming an Exceptional Leader. Radiol. Technol.75(6).457-67.

Yonghee, H. \& Youngrye, P. (2013). Effects of Selfleadership and Job Involvement on Clinical Competence in General Hospital Nurses. J Korean Acad Nurs Adm 19(4). 462-469.

Yun, S., Cox, J. \& Sims, H. P. (2006). The Forgotten Follower: A Contingency Model of Leadership and Follower Self-Leadership. Journal of Managerial Psychology, 21 (4), 374-388. 

